\title{
Self-Interest in a Hostile World
}

Hochwälder is all too aware of how easily the voice of conscience can be drowned out by the other demands placed on an individual. In the majority of his plays characters struggle to live in a hostile world in which callousness and selfishness seem prerequisites to survival. As a result, wealth and power are often viewed as the only things worth attaining, while those who have already attained such status jealously guard it.

This is certainly the case in the early play, "Der liebe Augustin"1, where not even the ravages of plague will stop the protagonist's fellow Viennese from putting their own interests and profits first. Augustin himself, having lost his wife, is able to regain his old job as entertainer when disease spreads through the community, for he alone seems able to find any humour in dark times. However, his cynical approach to life, the result of the loss of his beloved wife, is ultimately dehumanising and he is just as unable to return to normal life when the calamity is past as his fellow citizens are to learn from the experience.

Corruption and greed are also strong features of the later plays, Esther. Ein altes Märchen, neu in dramatische Form gebracht and Das heilige Experiment. In both dramas, the powers that be, and those that serve them, are shown to be unethical, self-serving, and prepared to protect their own interests at any cost, be that the sacrifice of a minority people or a genuine humanitarian undertaking that threatens to undermine an unjust system.

Likewise, morality seems to have little place in the dramas Hôtel du Commerce. Komödie in fünf Akten nach Maupassants Novelle 'Boule de suif' and Die Herberge. Dramatische Legende in drei Akten. The dominant motivation of most of the characters in both plays is self-interest and acquiring or protecting wealth. While lip-service is paid to such notions as justice and honour, the behaviour of supposedly respectable citizens is contrasted to those willing to listen to an inner voice: Schimke and, to a lesser extent, Jurgis and Staschia in Die Herberge; and the prostitute, Elisabeth, in Hôtel du Commerce.

In other plays, the social milieu is not so significant. Nevertheless, a world of greed and avarice becomes evident through the central characters. Hence in "Trommler. Hörspiel", the natural desire of parents to search for their longlost son is corrupted when they set their sights on a stranger's money, with tragic results. On a far more comic note, Lutmer in "Kaufmann und Kuenstler.

1 Fritz Hochwälder, "Der liebe Augustin", ts., 1934, Hochwälder Nachlaß, Wiener Stadtund Landesbibliothek, Wien.

2 Fritz Hochwälder, "Trommler. Hörspiel", ts., 1932, Hochwälder Nachlaß, Wiener Stadtund Landesbibliothek, Wien. 
Komödie" ${ }^{3}$, allows his ego to reign in the belief his artistic talents will lead to fortune and fame, with laughable results. A similar lesson is demonstrated in Der verschwundene Mond, when the protagonist misuses his genuine artistic abilities to acquire wealth, in the misguided belief it will buy him happiness. While at the start of Donnerstag the protagonist, Pomfrit, has already learned that striving and success do not necessarily guarantee happiness, he remains self-obsessed and is prepared, initially at least, to do anything to find contentment, even to sacrifice his own conscience.

This last play takes the theme of self-interest to its ultimate conclusion, for should the dictates of personal interest be pushed so far that any moral sense is not just suppressed but destroyed, then the human race may lose its very essence, that which makes it, even in the most barbaric of worlds, human ${ }^{4}$.

Human kindness is certainly not a noticeable feature of the world of "Der liebe Augustin", in which the protagonist is firstly a victim of callousness and selfishness, then later, when disaster strikes the whole community, an ironic commentator on the folly of those around him.

In this play Hochwälder is no longer under the influence of Expressionism, which weighed down the earlier plays "Trommler" and "Jehr. Schauspiel", and now looks to the traditional Volkstheater for his dramatic model ${ }^{6}$. The play is rich in Viennese dialect, has its share of stock characters, and uses humour and song to make its social criticism. It is also the first time Hochwälder uses the effective and practical dramatic device of limiting the action to a single location.

Set immediately before, during and after the period when the plague swept Vienna in 1679 , the calamity that befalls the population turns the social order on its head and exposes its underlying ruthlessness. The harshness of this society becomes apparent in the opening scenes. The protagonist, Augustin, has been replaced as entertainer at the inn because he has lost his sense of humour since his wife became gravely ill. If Paunzinger, the innkeeper, is to be believed, Augustin is the engineer of his own problems, for he loves his wife too much: "Er [Augustin] ist ein guter Kerl, das ist sein grosser Fehler. Wie kann man sich so an ein Frauenzimmer hängen [...]" (DLA, 7). Paunzinger, while hypocritically claiming "Man is ja kan Unmensch" (DLA, 6), nevertheless has no compunction in dismissing Augustin when he sees him as "[...] a Nummer vom vorigen Jahr" (DLA, 3). Isolated when he needs support

3 Fritz Hochwälder, "Kaufmann und Kuenstler. Komödie", ts., undated, Hochwälder Nachlaß, Wiener Stadt- und Landesbibliothek, Wien.

4 This theme which is continued on from Donnerstag in 1003 and Lazaretti oder Der Säbeltiger, will be explored in Chapter 7 .

5 Fritz Hochwälder, "Jehr. Schauspiel", ts., 1932, Hochwälder Nachlaß, Wiener Stadt- und Landesbibliothek, Wien.

6 Hochwälder professed that the Volksstück was the greatest influence on his dramatic output (Im Wechsel der Zeit, 92-93). However, this is one of the few plays he wrote which is clearly indebted to the genre - a problem evident from Elwood Venton Chandlee Jr.'s slim dissertation, "Fritz Hochwälder as Heir to the Viennese Hanswurst Tradition with a Hochwälder Bibliography". 
most, Augustin can only envy the fool's apparent lack of perception: "du hast es gut. Du bist bled" (DLA, 24).

Augustin also receives little sympathy from his successor and rival, Müchtel, who has benefited most from Augustin's trouble and can now smugly crack jokes about it. However, times are about to change and when Müchtel suggests Augustin might find a better audience among the dead (DLA, 6), he inadvertently signals what is to befall Vienna: amid the death of the plague Augustin is again able to perform: Such hints of events to come are a typical dramatic device used by Hochwälder, and there are other portents of doom, such as the mysterious and terrible warning heard in the night by the peasant (DLA, 9).

In Act II Augustin finds himself, by default, back in his old role as entertainer. Now that misfortune has hit the wider community, he is the only one able to make light of the situation, having already lost his wife. While he must contend with his personal grief, the opening scene sees him drunk (DLA, 27) ${ }^{7}$, unlike those around him he no longer fears for himself:

Ah, mir machen die Zeiten nix, Wenn [sic] jetzt nicht einer lustig wär, schauerten wir traurig aus...Und was könnt mir Schlimm's g'schehn... dass ich lebendig bliebert! - Und das ist auch ausz'halten. - Wenn er mich aber derglengert, der Obere...bin ich bei ihr.

(DLA, 31)

His attitude towards those around him becomes increasingly cynical and callous. He recognises that one of the main reasons that people stay in Vienna, and risk succumbing to the plague, is the fear of losing profits they might otherwise make:

Der Fleischhacker will noch Fleisch verkaufen, der bildt' sich nämlich ein, er hat z'wenig verkauft: der Wirt will net abreisen, der hat noch z'wenig Leut' b'soffen g'macht; die Medizis grausen sich am meisten vorm abstauben [sic] - die haben net fertig studiert, was letzten's die Schuld an der Seuch hat, und bevor's das nicht herauskriegt hab'n, finden's kein Ruh [...]

(DLA, 31)

Augustin argues that one can only find humour in a situation where: "A jed derschlagt sich für sein kostbar's Leben, und bringt sich vor Sterbensangst um!" (DLA, 31).

His cynicism seems justified by the behaviour of those around him. Paunzinger, ever concerned with profit, complains that people are now drinking on credit, covering themselves for the eventuality that they may die (DLA, 33) and given any opportunity they are prepared to steal from the dead (DLA, 38). A visible sign of the times comes in the form of the idiot, Toni, who, like Augustin, depends on the patronage of others to survive, and now in bad times has become emaciated (DLA, 42).

${ }^{7}$ Cf. III, 44. 
It is against this background, that Augustin explains his behaviour to Marie, who admires him for making people laugh during dark times:

Weisst, Mariedl, wie's den Leuten gut gangen is und da herin [sic] alles g'lacht, g'soffen und g'fressen hat, hab' ich schwer's Herzweh g'habt mit mein Lenerl [his wife]... Und das Herzweh is nicht um soviel weniger worden, seit das Elend über alle Leut kommen is. Aber wie nehmen's die Leut auf und wie hab' ich's tragen! - Jetzt bin ich allein, ganz allein und mir is gu [sic] so... Und um mich herum sind viel Leut', aber wenig Menschen... Der stirbt, der wird sterben... 's is alles miteinand net wichtig... Und grad jetzt is eine richtige Zeit für Spass-macher, die ihr Gewerb verstehn... die Leut soll'n lachend z'grundgehn, hab ich mir vorg'nommen! Soll'n nicht dran denken, wie's um sie steht! - Der Wein, die Buhlweiber und ich - wir sein aus ein'm Stoff! Der Wein ist giftig, die Buhlweiber von französischem Feuer ang'füllt und ich bin der Schlankel, der den Leuten das Hirn aussernimmt!

(DLA, 44)

Such cynicism, however, becomes self-destructive, and Augustin's behaviour towards the dying Müchtel, despite provocation, is just as inhumane as the attitudes of others to his earlier difficulties. He sarcastically sings his rival's song to him, which had earlier been used to taunt Augustin, then offers no help as Müchtel collapses, and, finally, callously removes the body of his rival from the pub because it is upsetting the patrons (DLA, 49-50). Such behaviour is rejected even by the Narr, who has not run away in fear with the others when Müchtel died, but who now leaves in despair at Augustin's cruelty (DLA, 52). The act ends with Augustin alone with his cynicism. He recognises that he is only of use while times are bad, and with heavy irony sings:

So lang die Zeit so schlecht,

Is allen Menschen recht,

Dass' gibt in unserm Wien

Ein' lieben Augustin!...

(DLA, 54)

This prophesy is fulfilled in the final act, where, following the return of good times, Augustin's behaviour is again inappropriate and finds no favour with the Viennese intent on celebrating the return of good times. While the others are enjoying themselves, Augustin finds himself brooding, and, as a result of his own experiences, he cannot share the general confidence in the future: "Achtundneunzig Paarl'n heiraten, hab i g'hört... Die Leut' wer'n net g'scheiter..." (DLA, 59). Unable to enter into the spirit of things, when asked to speak, his comments at first perplex the guests at Marie's wedding:

Ich leb', weiss nicht wie lang,

Ich sterb, und weiss nicht wann,

Ich fahr, weiss nicht wohin, 
Then when asked to sing by the bride, his unsuitable song of death earns even her anger:

MARIE: Pfui! - Das is kein Hochzeitslied!

AUGUSTIN (steigt vom Podium): Ich wiess [sic] kein anders...

MARIE: Dann sei stad, bei uns!

AUGUSTIN: Das könnt' ich auch tun...

The idiot's familiar song for alms, non-threatening as it is, earns more favour among the celebrating guests (DLA, 75). The melancholy Augustin slowly leaves, with a warning for the future: "as [sic] Unglück is nur verschwunden... Morgen is' leicht wieer [sic] da! Mich werden's noch brauchen, mein ich [Hochwälder's emphasis]..." (DLA, 76).

His pessimism would seem confirmed by the behaviour of most of the other characters in the play, for nothing seems to have been learned from the recent experience. Paunzinger, who has already been seen to have little consideration for the suffering of others, more clearly than any other figure demonstrates the self-interest and selfishness of this society. Representative of the greedy businessman, his prime concern is always profit, even when his daughter is involved. When Marie is offended by Müchtel's bawdy song "Mariedl, wohin?", his initial response is simply: "Na, na a Wirtstochter wird doch noch an Spass verstehn!" (DLA, 5), for he knows that Müchtel is good for business. It is only after Marie has stormed off, and left her father to serve the customers alone, that he reprimands Müchtel for annoying her (DLA, 7). Later, when Marie is again outraged, this time by Augustin bringing the prostitute, Regine, into the inn, Paunzinger immediately recognises the potential for attracting more custom and takes no action (DLA, 36). The plague does not awaken any latent humanitarianism in the landlord, merely raising financial concerns, both about the money he is owed by customers and the fact that he has lent cash to Dr. Genz, the harbinger of the bad tidings (DLA, 25). Later, he shows no concern for the fate of his patrons when told they have all died:

PAUNZINGER: Was d'net sagst! Alle san gstorben!...Gut, dass ich gschlafen hab', sonst hätt's mich graust... Aber Jesus Maria und Josef! wo [sic] is das Mariedl?!

AUGUSTIN: Sorgen S' Ihnen nicht. Die Marie war net dabei. Die is schon längst schlafen 'gangen.

PAUNZINGER: Gott sei Dank! Um die andern is eh kein Schad'....

(DLA, 51)

So it is highly ironic that many of the platitudes expressed in the final act come from Paunzinger. He pays tribute to the supposed spirit of the Viennese, which had hardly been evident during the plague, stating: "Der Weaner geht net unter!" (DLA, 60, 71), and even allows himself the hypocrisy of claiming 
love for his fellow man: "Mir Weaner, ob arm oder reich, grossschädelt oder teppert - san a anzige grosse Familie!" (DLA, 61).

Paunzinger is representative of the population at large, and the characters of Müchtel and Hoffkirchen are also shown to be selfish and self-serving, while the comical drunken trio of Ferdl, Franzl and Pepi show incorrigible irresponsibility both before and after the plague.

The positive figures of the play are Marie and the dedicated doctor Genz, whose optimism for the future provides an alternative, if not a completely convincing one, to Augustin's pessimism ${ }^{8}$.

Marie remains a one dimensional character ${ }^{9}$, whose function is, through her own decent behaviour, to highlight the inadequacies of those around her. She defends Augustin against the harsh treatment of her father (DLA, 8), shows concern for Augustin's sick wife (DLA, 13, 23), and demonstrates moral fortitude in the face of Müchtel's cowardly suggestion they flee the plague together (DLA, 34). She gravitates toward the "good" men in the play, firstly Augustin, and then when rejected by him (DLA, 43), to Dr. Genz, whom she agrees to marry (DLA, 48).

Genz, on the other hand, is a much rounder character. His dedication to his work as a doctor is evident from the first act, when it is revealed that he does much work amongst the poor, despite meagre remuneration (DLA, 12). This continues during the plague, when he goes amongst the dying to do what he can, in sharp contrast to the wealthy and more respected Dr. Hoffkirchen, who keeps his distance from the sick and hopes for a miracle (DLA, 26-27). Genz puts his faith in the ability of society to take charge of its own future and he scornfully rejects superstition: "Es ist kein Gottesgericht, diese schreckliche Seuch'! Vielmehr durch eure eigene Dumpfheit entstanden und genährt. - Was Menschen trifft, kann auch von Menschen abgewendet werden!' (DLA, 28).

It is this conviction that persuades Marie to accept his proposal so together they may help rebuild the world, once the plague has passed: "Wir sind jung, wir wollen gleich danach anfangen, die Welt wieder tüchtig zu machen!" (DLA, 47). This confidence is the closest the play comes to suggesting any possible path to a better society.

However, Genz is not without his failings, and shows the same propensity to gamble demonstrated by his countrymen during the plague, when he becomes involved in a game of dice (DLA, 16). Despite being implored by the virtuous Marie to stop (DLA, 19, 21), he gets caught up in the excitement and even turns to Paunzinger to borrow money (DLA, 21). This very human weakness,

8 Eileen Murphy ("The Drama of Fritz Hochwälder", 43) argues that it is the optimism of Genz and Marie which prevents the play from ending on the depressing note of "Trommler" and "Jehr", but, as will be seen, the play's conclusion is hardly positive.

9

According to Hochwälder, Hans Weigel, on hearing the news of the birth of Hochwälder's daughter, wrote "hoffentlich ist das die erste Frauengestalt, die Dir gelingt" (Im Wechsel der Zeit, 55). Certainly it is hard to think of a convincing major female figure in Hochwälder's plays, with the possible exceptions of Theresa Tallien and Elisabeth Rousset. Marie is an early forerunner of other weak female characters such as Lilli Szekely in "Casa Speranza" and Rouzha in Lazaretti oder Der Säbeltiger. 
suggests a temptation to be led by others that proves telling in the final scenes.

In Act III, it becomes clear that nothing has been learned from the recent suffering. This is comically shown in the account of the drunkard Franzl, who tells how he has just got married along with his two drinking companions, Ferdl and Pepi, only to lose their wives during the post-nuptial celebrations. He tells Paunzinger of the priest's sermon, which echoes Genz's earlier sentiments:

[...] Dann aber bei der Predigt hat der Pater Abraham a Sancta Clara uns so sauber z'samm' putzt, dass mir glaubt ham, es bleibt nix mehr übrig von uns!... "Da habt's es, ihr Bande!" hat er g'schrien! - "was ihr ang'stellt habt's in unserm Wien! merkt's es euch!"... und immer fort und fort g'schimpft wie ein Rohrspatz. Einmal hat er g'meint: wann wir's so weiter treiben wie vorher, so wird die letzliche Plag' und Seuch' net die letzte g'wesen sein... Also, endlich kommen mir aus der Kirchen aussi da war'n mir drei ganz wach im Hals, weil der Herr Pfarrer so geschrien hat... und mir hab'n einen Durscht g'habt auf Tausend! [...] (DLA, 62-63)

This is a theme that Genz tries to take up himself later, but his talk of the necessity for future planning is quickly dismissed by Paunzinger and the others, and he sits back down laughing (DLA, 71). It is even more significant that after Augustin has cast a dampener on proceedings with his depressing song, it is Genz who restores the festive mood with a verse that sums up the carefree irresponsibility that he knows could lead to future disasters:

Gott liess den Kaiser nicht,

Wie er nicht liess die Seinen,

Die Pest liess nach in Wien, Das Best' wird bald erscheinen!

[...]

Ein Weh' ist weg von Wien, das Wohl wird drauf erscheinen,

Gott schenkt den Freudenwein und man hört auf zu weinen,

Gott geb, dass Stadt und Land fortan in Wohlstand steh',

Und Wien, in Ewigkeit, bleibt ohne Weh!

(DLA, 76)

That even those who recognise the need for change are so quickly caught up in the return to the ways of old, can only justify Augustin's closing pessimism. In Genz's faith in the power of human endeavour to change things for the better there is an element of what could possibly be taken to be guarded optimism in the play ${ }^{10}$. But the behaviour of the characters in the play means that any such hope is, at best, tentative. Greed, indifference to the plight of others, and general irresponsibility are all traits shown by the Viennese characters, and the message of the play is that until people overcome these human weaknesses, as long as there are "viel Leut', aber wenig Menschen"

10 Murphy, 43. 
(DLA, 44), suffering will remain in society. In light of this, Eileen Murphy has correctly seen a similarity with "Der liebe Augustin" and the much later play Donnerstag, both of which combine elements of the morality play and the Volksstück: "[...] the ideas behind the two plays are similar, as they point to the importance of spiritual values and in particular love of one's fellow men. These plays also satirize the complacency of the Viennese people". 11

While the central themes of the plays differ, the society portrayed in Esther has much in common with that of "Der liebe Augustin". It too is based on greed and self-interest and those that inhabit it seem unable to learn from experience, and are thus doomed to repeat their mistakes.

The primary concerns of Esther are power, politics and anti-Semitism, with the play intended as a "zeitloses Symbol [Hochwälder's emphasis] des jüdischen Schicksals in dieser Welt"12. Allegorical in form, its obvious allusion to the rise of Hitler and National Socialism will be examined later, but again the unscrupulous behaviour of most of the characters in the play contributes to calamity.

While self-interest is not the central focus of the play, it does provide motivation for many characters, including, it initially seems, the central character of Mordechai, who, in fact, plays a much more significant role than the Titelheldin Esther. When he is introduced, it is very tempting to see similarities with the character of Berullis in Die Herberge, since avarice seems to be one of his strongest traits ${ }^{13}$. The Jewish protagonist is involved in a heated exchange with the businessman Dalphon about money he is owed, and like the character of the later play, insists on his legal rights. Furthermore, he is also referred to by his debtor as "unbarmherzig" in his pursuit of money (I, 12). Later when Meres and Tharsis refer to the thing closest to his heart, meaning Esther/Hadassa, Mordechai himself immediately assumes they are talking about money $(I, 15)$.

While similarities with Shakespeare's Shylock in The Merchant of Venice are unmistakable and deliberate ${ }^{14}$, as testified to by his arrogance, pride and

11 Murphy, 43-44.

12 Fritz Hochwälder, untitled and undated notes on Esther [c. 1940?], Hochwälder Nachlaß, Wiener Stadt- und Landesbibliothek, Wien.

13 It should, however, be noted that Berullis was in no way conceived of as a Jewish character and that Hochwälder felt strongly enough about the assumption of a Jewish stereotype to take issue with Hanns Ernst Jäger's portrayal of the part in rehearsals at the Burgtheater, complaining that he "verjüdelt' im zunehmenden Mass seine Rolle" (Brief an Prof. Erhard Buschbeck, Direktion des Burgtheaters, 6 April, 1957, Hochwälder Nachlaß, Wiener Stadtund Landesbibliothek, Wien). Jäger subsequently apologised, noting he had previously played Shylock with great success! (Hanns Ernst Jäger, Brief an F.H., 8 April 1957, Hochwälder Nachlaß, Wiener Stadt- und Landesbibliothek, Wien).

14 Hochwälder certainly had Shylock in mind when planning the play:

Vorwurf: Mordechai vershylockt - Mordechai Vorbild von Shylock!!! - Wie Shylock besteht Mordechai auf seinen Schein! - Hier Fleisch des einzelnen - an sich berechtigt - dort, Mordechai, gerechtfertigte Rache - - - S Shylock wird betrogen -- Mordechai gänzlich im Gegensatz zur aller Historie der Galuth, nicht, siegt!!! [...] 
love of money, he is given a much more humane and sympathetic side than his Venetian predecessor or the usurer in Die Herberge. Unlike Berullis, he has not devoted himself to the acquisition of wealth for his own sake, but to provide for his niece, whom he has raised from a baby since his brother's death. While his ambitions for her will ultimately be shown to be foolish, his actions are nonetheless not selfish, but born from a desire that his niece should not have to endure the indignities and adversity he has undergone by being so readily identified as a Jew:

[...] wenn man mich hört sprechen, weiß man, woher ich komme, trotz meines Geldes! - Aber daß man soll merken an Hadassa [Esther] niemals, woher sie kommt - dafür hab ich gearbeitet mein Leben lang, und hab nicht gefragt: was kost' das? - was sonst aus Gewohnheit ist meine erste Frag' bei allem... Und hab ich nicht erreicht mein Ziel? Ist sie nicht eine junge Dame, gebildet und gut erzogen und vornehm anzusehn wie eine Königin, als wär sie aufgewachsen in der Aristokratie... Also hab ich gezeigt, daß es gibt einen Aufstieg auch für ein jüdisch Kind!

Such is his concern to look after his niece, that he takes on an unpaid lowly position at the court just to be near her (I, 17-18).

Mordechai has numerous failings, such as arrogance, a disdain for the poor not dissimilar to Haman's, and a naive faith in authority, but greed and pure selfinterest are not amongst them. Even when he sees the threat to himself and Esther, his overall concern turns to his people, the Jews, and how to avoid the pogrom planned for them.

Such altruism is not shared by many other characters. The king sets the example by being intent on protecting his own position, rather than having any concern for governing well. As the ruler and his ministers grapple with an increasingly volatile political situation, the minister of police, Charbona, elaborates just what the problem is: the country has been mismanaged to such a degree that it is bankrupt, with wealth concentrated in the hands of an elite few, while the majority lives in poverty. Since, however, those in government are amongst the haves rather than the have-nots, the king has no intention of rectifying this situation (I, 40-41). The desire to cling to power leads to the dangerous alliance with Haman, the potentially disastrous results of which are averted, by chance, at the end of the play. Yet, as the king makes clear to Mordechai, injustice and Realpolitik will continue to be practised at the expense of the Jews (I, 81).

The king's subjects show a similar lack of scruples when it comes to protecting their own interests, typified by the confidantes of the king, Meres and Tharsis. Seeing the way the tide is turning they hatch a scheme to win favour with the rising force of Haman, while not severing ties with the king, in case he can cling to power (I, 44, 50).

While all this is taking place, Haman is able to exploit general dissatisfaction

- Fritz Hochwälder, untitled and undated notes on Esther [c. 1940?], Hochwälder Nachlaß, Wiener Stadt- und Landesbibliothek, Wien. 
to organise forces against the government. His support comes from those who feel they would do much better if the government fell, and who are motivated, like those in power, purely by selfish reasons: Dalphon feels he has been ruined by Mordechai; Vajesata, a poet, has been usurped at the court by Meres; Porata has been overlooked for command in the army (I, 30); and Prince Parsandata, who later succeeds Haman, is seeking to restore his family's fortunes (I, 61). Despite any professed concern for the country, they are all motivated purely by self-interest.

Disaster is averted by the good fortune of both Mordechai and Esther being in the right place at the right time to save the king. However, if Augustin's parting words at the end of "Der liebe Augustin" paint a pessimistic picture for the future, then the conclusion of Esther is even bleaker. The anti-Semitism exploited by Haman, will certainly return, as the defeated Haman is aware (I, 77 ), and as the king admits to Mordechai:

Für diesmal ist dein Volk gerettet durch ein sonderbares und zufälliges Zusammentreffen seiner eigenen Bedrängnis mit der Gefährdung des Staats... Fast schäm ich mich, es dir zu sagen, armer Mann... : Grade durch mich wird in naher Zukunft dein Volk zu leiden haben - da wir nun einmal wohl oder übel die allgemeine Unzufriedenheit ablenken müssen auf den Rücken der Machtlosen... So ist's... das ist der Lauf der Welt und der ist immer der gleiche, unveränderlich, seit Jahrtausenden...

Those in power, the monarch included, still cling to their privileges with little idea how to govern the country out of crisis. The only ones to learn from the experience are Esther and her uncle, who can do little but walk away from the corruption they have witnessed.

Those with power and influence in Hochwälder's drama, Das heilige Experiment, also demonstrate the same callous self-interest shown in Esther. As in the earlier drama, the brutality of society is not central to the play, but greed, exploitation and Realpolitik play a key role in the destruction of the Jesuit state in Paraguay. More significantly, the issue of materialism and selfinterest, particularly regarding the motivation of the Indians, has led to some secondary literature being diverted from the central concern of the play.

In fact, these themes play a much bigger role in an earlier draft of the play, entitled "Die Jesuiten in Paraguay. Schauspiel in drei Akten"15. This play, which lacks the subtleties and complexities of the moral dilemmas in Das heilige Experiment, focuses less on the Provincial than on the King's envoy, Miura. The Spaniard is ultimately forced to confront the fact that his mission to disband the Jesuit reductions is wrong and unjust, leading to the decision to refuse to go any further in his task and to his replacement by his more ruthless subordinate, Villano (DJIP, 65-72). Until he reaches this point, however, he is

15 Fritz Hochwälder, "Die Jesuiten in Paraguay. Schauspiel in drei Akten", ts., 1941, Hochwälder Nachlaß, Wiener Stadt- und Landesbibliothek, Wien. 
primarily motivated by the profit they hope to make from destroying the reductions. Miura arrives with a preconceived idea of the Jesuits as "Heuchler" and "Goldraffer" (DJIP, 27), and is convinced that the Jesuits have amassed a secret treasure behind Spain's back. He and his men will be entitled to a third of any treasure found as reward (DJIP, 30). Such is his understanding of the world that he has great difficulty in grasping the fact that the reductions have no need for money or gold (DJIP, 34-38). When the truth comes out, both Miura and Villano realise they have been tricked into doing the crown's dirty work with the promise of non-existent riches (DJIP, 66). Miura, however, has been doubly deceived with his belief that their mission was also just, something which Villano never believed (DJIP, 69). It is left to Villano to spell out to his superior what their real role is:

VILLANO: [...] Macht euch nur vertraut mit dem Gedanken, dass wir leer abziehen müssen. Vielleicht, dass wir uns schadlos halten können bei der Verteilung des Privatbesitzes der Patres: ein Ring... ein silbernes Kettlein... oder auch ein Edelstein, ein kleiner...

MIURA: Was redet ihr da: Sind wir denn Wegelagerer oder Diebe?

VILLANO: Was denn sonst? - Und, wenn ihr so auffasst - noch Schlimmeres: Wegelagerer, Diebe, Mörder, Henkersknechte [...]

In Das heilige Experiment both Miura and Villano are radically different chaacters, and pecuniary reward is no longer an issue. Nevertheless, greed, materialism and self-interest still play a significant role.

Politically both the Spanish State and the Church are motivated by selfinterest in seeking the destruction of the reductions. The crown has been only too willing to accept the complaints from Spanish settlers and rumours of amassed wealth and arms as true, since they provide ready grounds for destroying the Jesuits' work. The King's representative, Miura, reveals the real reason for this to the Jesuit leader: the example of love and justice set by the Jesuits in Paraguay, poses a very real threat to the Spanish Empire, based as it is on conquest and injustice (I, 117). Likewise, the Jesuit Order, as represented by the Legate, Querini, chooses to put its own interests ahead of all other considerations. Survival of the Order in Europe, which depends on the crown's support, is more important than the welfare of its South American charges: "Es geht um den Bestand des Ordens - und Ihr [the Provincial] sprecht von hundertfünfzigtausend Menschen!" (I, 124).

Individual selfishness is shown by the behaviour of the Spanish settlers in Buenos Aires. Their hostility to the Jesuits is based purely on a desire to be rid of the competition posed by the reductions. As early as the fourth scene of the play, Bustillos complains to the Provincial that the presence of his Indians in the city is having an unsettling effect on the settlers' slaves:

BUSTILLOS: Das böse Beispiel sind Eure Indios für die unsern! Die Arbeit stockt. Es gibt noch Revolten, wenn Ihr das nicht abstellt! 
PROVINZIAL: Was sollten wir abstellen?

BUSTILLOS: Daß von Euren Indios erzählt wird, wie in Eurem Zauberstaat Milch und Honig fließt. Wie süß das Christentum wär ohne Sklaventreiber. Und so.

This theme of unfairness is taken up at the hearing into the Jesuits' running of the reductions held by Miura. Here, Bustillos is joined in a chorus of complaint by fellow settlers, Quesida and Catalde. Their accusations that the Jesuits spread propaganda amongst the Indians, provide unfair competition and are arming for war (I, 106-109), are easily refuted by the clerics, who are supported by the Dutch trader, Cornelis (I, 109-114). Their complaints simply emphasize the fact that the Jesuits treat the Indians much better than they do themselves, and, as a result, produce a better product. Yet, their complaints have served the Spanish government well, since they have provided a ready, if dubious, justification for destroying the reductions.

But the most important aspect of self-interest in the play is the suggestion that the Indians themselves are motivated by material considerations, for it is this accusation that causes the Provincial the most doubt about the moral validity of the Jesuits' work in Paraguay. This issue is first raised by the Bishop of Buenos Aires, whose hostility arises from the competition for influence in the region presented by the Jesuits. He accuses the Indians of not being Christians at all:

Man hat unter dem Vorwand der Religion eine Utopia aufgerichtet, die den Indios Nahrung, Kleidung, Sorglosigkeit, Sicherheit bringen sollte. Und man hat, anstatt aus Heiden wahre Christen zu machen, aus heidnischen Indios schnöde Materialisten gemacht. Wenn Christus nicht Brot, Fleisch, Herba-Maté garantiert, hat man kein Interesse fürs Christentum. Wenn nicht der Jesuit predigt, sondern ein anderer Diener der Kirche - ist dem Indio der Lehre Christi gleichgültig.

Such criticism is taken up by Querini, who has a similar desire to destroy the reductions. In his efforts to break the Provincial's resistance, he argues that such materialistic Christians are not what the Church wants (I, 122-123).

Certainly, having finally agreed to comply with his orders, this attack on the Indians troubles the Provincial. He questions the chiefs Candia and Naguacu, who earlier have asked that their people be allowed to join the reductions, and their responses seem to confirm his fears about their reasons for wanting to join the reductions. He tells them with resignation: "Oh - ihr seid von uns getäuscht worden. Christus verleiht keine Sicherheit, ernährt nicht, bekleidet nicht - er selbst ist arm und bloß..." (I, 133).

Critics have seen this question of materialism as compromising the Jesuits' spiritual position ${ }^{16}$, and some go so far as to suggest that the Jesuits them16 C. D. Innes, Modern German Drama. A Study in Form (Cambridge: Cambridge Univ. Press, 1979), 214-215; Harper, 53. 
selves have been seduced by the worldly qualities of their work. Marie Holdman lends some credence to Querini's position on the Jesuits' work in Paraguay by arguing that they have moved away from the spiritual teachings of their founders through their material success, indicated by their repeated references to their colonies as a "Staat" or "Reich" and the prominent placement on stage of a map of the settlements ${ }^{17}$. Alan Best goes even further:

The Jesuits in Paraguay had the luxury of security and they drew their Christian strength from what they created. As the Provincial belatedly realizes, they have been worshipping a graven image and it is the innocent, simple Indios who must pay the price for the Jesuits' reluctance or inability to stand alone $e^{18}$.

Yet such arguments put too much weight on the suggestions in the play that the Indians are motivated purely by the material rewards offered by the reductions. Certainly, they distinguish between the "Christus der Spanier" and their own Christ (I, 130), yet it seems particularly unkind to single out the Indians for displaying a certain amount of self-interest when this is a trait far more glaringly displayed by the enemies of the Jesuits. Furthermore, it seems unfair to criticise them for a lack of genuine Christian morals ${ }^{19}$, particularly in light of their "kindliche Gemütsart". They compare most favourably with the other Christians in the play.

The fact remains that the Jesuit state is to be destroyed for the basest reasons: greed and power. It is the exemplary nature of the religious enterprise that has made it a threat to others, rather than any inherent moral flaw. The momentary doubts the Provincial has about the integrity of the Jesuits' work occur after he has reluctantly agreed to the destruction of the reductions, and should be seen, in much the same way as can the investigation conducted by Miura, as an attempt to justify the decision after it has been made. The resolution of the play will be discussed later, but by then the Provincial's doubts are resolved, and the central issue is not one of religious misjudgement but of the difficult relationship between personal conscience and higher authority.

External forces, this time the victorious Germans, are also the catalyst for the action in Hotel du Commerce, in which the crisis of the Franco-Prussian War of 1870 exposes the questionable morality upon which French society is based, and provides characters with ample opportunity to display mercenary ${ }^{17}$ Holdman, 167-170.

18 Best, 50.

19 One critic has even gone so far as to call on Biblical sources to justify the Indians' behaviour, claiming they are simply following Christ's advice; "An ihren Früchten sollt ihr sie erkennen" (Gerlach, "Unterdrücktes Gewissen als Zentralmotiv in Fritz Hochwälders Heiligem Experiment", 362-363). While Gerlach contributes much to the debate on the play, and correctly observes that both the Indians and the work of the Jesuits are portrayed as laudable throughout the drama, the risks of any overly theological emphasis on the play should be noted, and Hochwälder himself observed that the milieu of the play had incorrectly branded him a religious author (Hochwälder, Im Wechsel der Zeit, 89). 
ruthlessness.

Hochwälder saw the play as a lesser work, referring to it as a "Nebenwerk", which was written as a "Zeitvertreib" and "Fingeribung", and which owed its initial success, indeed Hochwälder's first, largely to the director, Alfred $\operatorname{Radok}^{20}$. Certainly, it does not have the same depth and biting satirical edge of the Maupassant original, Boule de suif, upon which it is based, but within the limits of light comedy it succeeds well. In fact, Hochwälder uses the material provided by Maupassant's novella in a markedly different way than the Frenchman.

The propensity to put financial and personal interests above all else, shown by most of the characters in the play, is cleverly alluded to by the title itself, Hôtel du Commerce, which was suggested by Georg Kaiser ${ }^{21}$. While the name of the inn where the passengers stay is a common enough name in France for establishments which serve travelling businessmen and salesmen, and indeed is the name used by Maupassant ${ }^{22}$, it also encapsulates the willingness of most of the characters to trade Elisabeth's scruples for their own benefit. While the play shares most of the basic plot elements of the original novella, it differs enough in detail to make a comparison fruitful in exploring the dramatist's intentions.

Clearly many of these differences are for dramatic purposes. Restricting the action to the hotel itself not only simplifies matters from a staging point of view, but also emphasizes the fact that the travellers are trapped. The fact that the Prussian officer does not appear on stage is an effective dramatic device, with the Pickelhaube and sword mounted on the wall serving as a clever visual symbol for the threat hanging over the travellers, without necessitating his physical presence.

The introduction of Louis is a major change from the original, and his role is much more than simply to add dramatic tension in the last acts by introducing the knife, and with it the possibility of murder or suicide. He significantly alters the overall impact of the story, particularly its ending, allowing Elisabeth a degree of dignity she does not enjoy in Maupassant's work ${ }^{23}$.

His appearance has led to suggestions of a clear and deliberate class divide in the play, with Donald G. Daviau observing:

Die Reichen sind alle korrumpiert, und die Armen sind ehrlich; so sieht die Welt in diesem vereinfachten Bild aus, in dem alle Charakere [sic] Stereotypen, wenn nicht Karikaturen sind. Der deutsche Offizier wird als

${ }^{20}$ Hochwälder, Im Wechsel der Zeit, 30.

21 Georg Kaiser, Brief an Fritz Hochwälder, abgestempelt 10. Juli 1944, Hochwälder Nachlaß, Wiener Stadt- und Landesbibliothek, Wien.

22 Guy de Maupassant, Boule de suif, Contes et nouvelles, vol. I, ed. Louis Forestier (Paris: Gallimard, 1974), 98.

23

Cf. Maupassant, 120-121. In the coach leaving the inn, Elisabeth is left silently crying to herself, ignored by the others. 
perfekter Kavalier dargestellt, der wieder zeigt, wie die Macht über das Recht triumphiert ${ }^{24}$.

This apparent black and white portrayal of rich and poor has prompted claims of Marxist intent, both by critics at the time of the première ${ }^{25}$, and in response to the 1986 revival of the play in Vienna, when both favourable and negative reviews saw parallels in the play to Brecht's famous dictum: "Erst kommt das Fressen, dann die Moral". However, Bortenschlager's view that this is incorrect and that the plays focuses on a "humanistischen Aspekt", is borne out by comments by the author. In an unpublished essay entitled "Maupassant und das Theater", the author expressed his opinions on the original novella:

[...] der zeitlose Konflikt zwischen Menschlichkeit und zynischem Egoismus, der im Grund nichts mit Krieg, Flucht, Besatzungstruppe oder sozialer Frage zu tun hat, gehört gerade durch die von Maupassant genial erfundene Fabel auf die Bühne, und sicherlich hätte ihr Urheber sie selbst dahin gebracht, wenn sich nicht sein Genie als vornehmlich der Novelle zugewandt erwiesen hätte ${ }^{26}$.

With regards to his own dramatisation, he also refutes any suggestion of political content:

Dem Bearbeiter liegt daran, zu erwähnen, dass es sicherlich falsch wäre, die Figur des in die Originalhandlung eingefügten Kutschers Louis als Politikum aufzufassen. Der Kutscher steht im Stück als Symbol für Uneigennützigkeit und Hilfsbereitschaft, und das sind Eigenschaften, die es glücklicherweise überall gibt ${ }^{27}$.

In fact, by choosing to focus on individual failings, on the conflict between altruism and egoism, Hochwälder loses much of the social criticism that is in the Maupassant story. Certainly much of this, such as the long description of the retreat and disarray of the French army, and the reaction to the loss and arrival of the Prussians in Rouen ${ }^{28}$, is not integral to the main story, and would certainly have been difficult to incorporate into the drama. Furthermore, the issues relevant to late nineteenth century France, are no longer of interest to a dramatist in the mid-twentieth century. What social criticism is to be found in the drama, that which has led to political themes being attributed to the play, largely originates in the Maupassant novella, and is not central to an

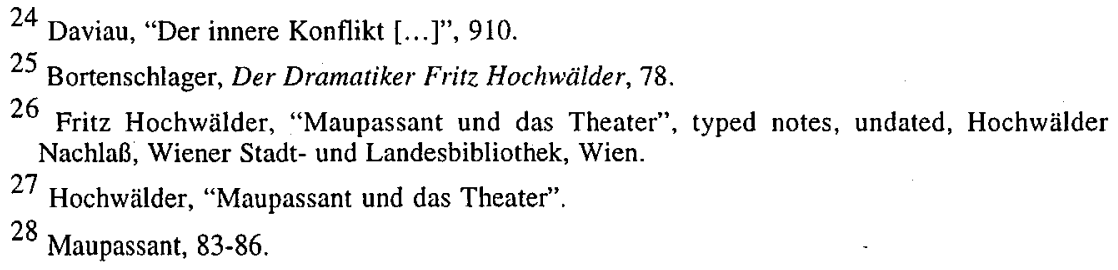


understanding of the play. Maupassant, particularly in his description of the characters, is very much attacking the social institutions of his time. After the reader learns of the dishonest business practices of the Loiseaux, and the sexual improprieties in the family histories of the Carré-Lamadons and de Brévilles ${ }^{29}$, it is observed with heavy irony: "Ces six personnes formaient le fond de la voiture, le côté de la société rentée, sereine et forte, des honnêtes gens autorisés qui ont de la Religion et des Principes" ${ }^{30}$. Much is made of the social and political gulf between, on the one hand, Elisabeth and the radical Cornudet, and on the other, the other passengers. The women naturally unite against the threat Elisabeth poses, "car l'amour légal le prend toujours de haut avec son libre confrère", while the men are united by wealth against the politics of the Republican Cornudet: "Bien que de conditions différentes, ils se sentaient frères par l'argent, de la grande franc-maçonerie de ceux qui possèdent, qui font sonner de l'or en mettant la main dans la poche de leur culotte". ${ }^{31}$ Clearly all have made provision to survive the crisis that has befallen their country.

Other minor characters in the novella also make the distinctions between rich and poor, and the uneven distribution of the burden of war between the haves and have-nots, quite clear. At the first meal in the hotel, Mme. Follenvie, the landlady, makes a scathing attack on war, which has not only cost her money but is seen as purely destructive and wasteful. She even goes so far as to suggest it would be better to kill the kings that lead nations to $\operatorname{war}^{32}$. Such sentiments are reinforced by the description of German soldiers helping out the locals, and by the explanation of the verger when questioned about it by the Comte:

Oh! ceux-là, ne sont pas méchants; c'est pas des Prussiens, à ce qu'on dit. Ils sont de plus loin; je ne sais pas bien d'où; et ils ont tous laissé une femme et des enfants au pays; ça ne les amuse pas, la guerre, allez! Je suis sûr qu'on pleure bien aussi là-bas après les hommes; et ça fournira une fameuse misère chez eux comme chez nous. Ici, encore, on n'est pas trop malheureux pour le moment, parce qu'ils ne font pas de mal et qu'ils travaillent comme s'ils étaient dans leurs maisons. Voyez-vous, monsieur, entre pauvres gens, faut bien qu'on s'aide... C'est les grands qui font la guerre ${ }^{33}$.

Such anti-militaristic views, which also implicitly suggest that war is dictated along class lines, also challenge the patriotism expressed by both Elisabeth and Cornudet who do not question the need to fight for one's country ${ }^{34}$.
29 Maupassant, 89-90.
30 Maupassant, 90.
31 Maupassant, 92.
32 Maupassant, 101-102.
33 Maupassant, 103-104. 
However, in the play, their patriotism remains unquestioned. Indeed, it is worth noting that in the play the only anti-militaristic sentiments expressed come from Elisabeth herself, after she has attended a baptism (I, 177), serving to underscore the portrayal of Elisabeth as a warm, caring person [see below]. Not only does Hochwälder, in contrast to Maupassant, leave Elisabeth's patriotic views unchallenged, he also tones down the visual presentation of the prostitute, showing her in a much more positive light. The simple stage instruction for Elisabeth's appearance, "überelegant in Pelz und Muff" (I, 143), is in sharp contrast with the description in the novella, which presents her as at once grotesque and yet desirable:

La femme, une de celles appelées galantes, était célèbre par son embonpoint précoce qui lui avait valu le surnom de Boule de suif. Petite, ronde de partout, grasse à lard, avec des doigts bouffis, et étranglés aux phalanges, pareils à des chapelets de courtes saucisses, avec une peau luisante et tendue, une gorge énorme qui saillait sous sa robe, elle restait cependant appétissante et courue, tant sa fraîcheur faisait plaisir à voir. Sa figure était une pomme rouge, un bouton de pivoine prêt à fleurir, et làdedans souvraient, en haut, des yeux noirs magnifiques, ombragés charmante, étroite, humide pour le baiser, meublée de quenottes luisantes et microscopiques.

Elle était de plus, disait-on, pleine de qualités inappréciables ${ }^{35}$.

Religion is also portrayed far more favourably in the play, and further emphasizes the positive attributes of the central character, a point worth noting in light of comments made by Hans Vogelsang, who dismisses the play as "ein krasser Mißerfolg", and who seems particularly offended by the fact that it is one of the nuns who ultimately persuades Elisabeth to sacrifice her principles $^{36}$. It is hard not to share U. Henry Gerlach's view ${ }^{37}$ that Vogelsang could not have been familiar with the original, for the portrayal of the nuns there is far from complimentary. In the novella they remain nameless. One is described as having a face horrendously pitted by smallpox scars, the other as suffering from tuberculosis. Later, when it is revealed what their mission is, the older nurse is described as a tough, camp-following nun: "[...] une vraie bonne sœur Ran-tan-plan dont la figure ravagée, crevée de trous sans nombre, paraissait une image des dévastations de la guerre", with a fanatical faith, for which she would sacrifice father and mother without a thought, were it God's will ${ }^{38}$. When the travellers have finally succeeded in getting Elisabeth to give

34 The narrator also questions Elisabeth's staunch support for Napoléon III, whose government is described as despotic.

35 Maupassant, 91.

36 Hans Vogelsang, "Das klassizistische Ideendrama Fritz Hochwälders", Österreich in Geschichte und Literatur, 2 (1958), 227.

37 Gerlach, "Das Motif des unterdrückten Gewissens in den Dramen Fritz Hochwälders", 57. 
in, Maupassant's nuns even go so far as to partake in the celebrations by trying champagne ${ }^{39}$.

In the dramatisation the nuns play a minor, but not insignificant role, for it is the revelation that they are on a mission of mercy to help sick French soldiers that is the telling reason for Elisabeth giving in to the officer's demands. In Maupassant this news does affect the protagonist ${ }^{40}$, but it is the Comte, adopting a fatherly, superior manner who finally convinces her to go to the officer ${ }^{41}$. Again the dramatist imbues the central character with more nobility than in the original, for it is for the humanitarian needs of her countrymen that she makes the sacrifice, rather than being gullibly persuaded by the smooth words of the aristocrat. This is reinforced when Elisabeth accompanies the nuns to a local baptism, prompted by the fact that she has a child herself, as Frau Loiseau informs her husband: "Ach - sie hat selbst ein Bankert - bei irgendwelchen Leuten in Ivetôt - und als sie vorhin das Gebimmel hörte - da war sie ganz aufgelöst - denke dir, das gefühlvolle Geschöpf!" (I, 171). While Frau Loiseau's sarcasm is quite clear, it does not carry the same weight as the narrator's observation in Boule de suif that the protagonist scarcely saw her child and never worried about him $^{42}$. In addition to this, Elisabeth's report about the baptism is far more substantial in the play than in Maupassant ${ }^{43}$ and shows Elisabeth to be a caring humanitarian:

Die Kirche war voll von Bauern - das ganze Dorf war da. Und alle starrten das Kind an - wie ein Gotteswunder! Das machte mich so nachdenklich... was ist denn ein einzelner schwacher Mensch - wahrhaftig nicht mehr als ein Wurm, der bloß lebt, um zertreten zu werden, und wie unendlich wichtig nimmt man ihn doch! Wieviel Gespräche, Hoffnungen und Wünsche gelten ihm, wenn er noch im Mutterleib ist; wie sorgfältig hegt und beschützt man ihn in der Wiege - und wie bald verfliegen die Jahre, und das, was heut noch ein hilfloses Wickelkind ist, krümmt sich wimmernd auf irgendeinem Schlachtfeld... ein Opfer - wofür? An all das mußte ich denken - und dann... ich bin gewiß nicht fromm... ich mußte beten... es ist manchmal gut, zu beten...

Far from being a subject of attack, the nuns are used in the third act to accentuate the positive and sympathetic characteristics of the protagonist, serving the central theme of the play which is the clash between egotistical self-interest and the dictates of one's conscience.

Throughout the play, Elisabeth's patriotism and resistance in the face of the
38 Maupassant, 113.
${ }^{39}$ Maupassant, 116.
40 Maupassant, 114-115.
41 Maupassant, 114-115.
42 Maupassant, 110.
${ }^{43}$ Maupassant, 111-112. 
enemy are portrayed as unquestionably legitimate, and born from an inner belief in what is right, as opposed to being motivated by selfishness. Her stand is repeatedly contrasted with the self-serving behaviour of her fellow travellers. In the opening act Louis correctly sums up their reasons for leaving Rouen: "Sie flüchten nicht vor dem Feind, sie flüchten ihrem Geld nach, das sie rechtzeitig ins Ausland verschoben haben [...]" (I, 144). This is later confirmed by conversations between the passengers, when it is revealed that the Loiseaux must get to Le Havre to receive payment from the French army for the bad wine that has been sold to them, that the Carré-Lamadons have transferred a sizeable fortune to England (I, 151), and that the Graf can expect all his losses to be covered by the new government $(I, 198)$ : "[ ...] der hat sein Schäfchen im trockenen" (I, 171). The attitude of most of the characters in the play is summed up by the opening exchange between the landlord of the inn and his wife, when he tells her they have nothing to fear as long as they do as they are told by the Prussians: "Wahnsinn wäre das: sich gegen die Besatzungsmacht aufzulehnen. Wir sind die Besiegten, wir haben zu kuschen..." (I, 143).

The nuns aside, Cornudet is the most sympathetic of the other passengers. He remains, however, a minor character overall, and his significance as a radical democrat clearly does not have the same satirical importance for Hochwälder as it did for Maupassant. He shares Elisabeth's patriotism and has a politician's rhetoric when it comes to the subject (I, 146, 153), but also the capacity to vacillate when action is required, having only stayed to help in the defence of Rouen until the Prussians arrived (I, 169). Nevertheless, he is not as ruthless and self-serving as the others, and if he does try to take the opportunity to avail himself of Elisabeth's services (I, 157), he does have the decency to try to disrupt their plan to persuade her to give in to the officer's demands (I, 179. 180 ), and does not celebrate when she goes to the German (I, 183-184). Indeed, he makes the others a little uncomfortable in the last act, when the prostitute has nothing for breakfast, by reminding them of Elisabeth's earlier generosity with her food (I, 198), and prefers to eat on his own rather than with them (I, 194). However, when it comes to decisive resistance in the face of the enemy, all Cornudet can offer, by comparison to Elisabeth, is lip service.

The difference between the heroine and the others is inadvertently revealed by a telling remark by Graf de Breville, when he fears they may be held to ransom: "Es gibt so viele, die sich handgreiflich gegen die Besatzungsmacht vergangen haben, aber unser Gewissen ist rein!" (I, 164). Their consciences, of course, have very little to do with their behaviour. The primary concern of those with money in the travelling party is to hold onto it; they are quick to try to disguise their wealth when they fear they may be held to ransom (I, 164) and do their best to dissuade Elisabeth from her patriotic resistance when they are financially threatened by it.

Subjugating conscience to expediency is far removed from the position taken by Elisabeth, who chooses, despite personal risk, to do what she believes to be correct. As she tells the others: 
[...] Geschäft ist Geschäft? - Ja, wenn ich so gedacht hätte, dann hätte ich ruhig bleiben können. Ganz Rouen war voll von diesen preußischen Offizieren. Aber schon als ich sie bei ihrem Einzug gesehen hatte, hat es mich gepackt! Das Blut ist mir vor Ärger geronnen! Den ganzen Tag habe ich vor Scham geweint. Ach, wenn ich ein Mann gewesen wäre! [...]

She may, as a result of her resistance in Rouen, have been forced to leave, but she remains unrepentant and far from afraid of the enemy. This leads her to reject two opportunities to escape suggested by both Louis and the landlord (I, $145,148)$.

Her courage is in sharp contrast to those around her, who might make disparaging remarks about their own troops and the Prussians (I, 155), but show little bravery or resolve themselves. This is shown most clearly on the two occasions when they decide someone must undertake action for the good of them all, but are each unwilling to do anything themselves. Firstly, they want someone to go out into the cold and dark to try to find some food from the local peasants (I, 148-150), and secondly, when they fear that Elisabeth may kill the officer, they need someone to intercede and save him (I, 190-192). On both occasions, after passing the task from one to another, they turn to the coachman, Louis, who refuses to help them.

Elisabeth's compassion for others, Prussians excluded, is also at odds with the behaviour of her travelling companions. This is most strikingly shown in the two meal scenes. In the first the prostitute shows her warm-hearted generosity in sharing her food with the others (I, 153-165), despite the fact they have treated her so shabbily on the journey (I, 114), while the meanness of the others is shown at the end when no one but Cornudet even considers that they should share their breakfast with her (I, 198).

While they are all initially prepared to champion her patriotic resistance (I, $155)$, expressing solidarity when they learn what the officer wants $(I, 168)$, once they realise that they may be delayed for some time, and their assets endangered, they hatch their plan to persuade her to give in (I, 173-175). From a position of support they now turn against Elisabeth, and justify this in a blatantly hypocritical manner. The prostitute's stand, which at the end of Act II was seen as a brave, patriotic gesture, is now viewed by them as the height of selfishness, and nowhere is such hypocrisy more clearly shown than in the exchange between Loiseau and the landlord:

LOISEAU: [...] Dieses Frauenzimmer hat keinen Anstand. In Rouen war sie für jeden zu haben - sogar für Kutscher ${ }^{44}$. Und hier, wo sie ihr schandbares Gewerbe einmal - in allen Ehren, möchte ich fast sagen -

44 This and Louis' earlier admission to having spent time waiting outside Elisabeth's in Rouen (I, 144) possibly suggests more to their relationship than meets the eye. However, the suggestion that Elisabeth was available to all, including coachmen, originates in Maupassant's story [110], where the figure of Louis does not feature, suggesting that Hochwälder has simply kept this remark, made by Mme Loiseau in the original. 
ausüben könnte - hier spreizt sie sich! Sollen wir vielleicht den Rest unseres Lebens hier verbringen?

WIRT gleichmütig: Von mir aus. Mir kann es nur recht sein! (Ab in die Küche.)

LOISEAU: Schuft! - Der denkt auch nur an seinen eigenen Vorteil! (Angeekelt:) Ah - was für Menschen sind das!

Loiseau is blissfully unaware of the irony of this last remark.

His belief that Elisabeth has no right to refuse to do what is her job, is taken up by the women, who now find the Prussian to be a fine officer and to be behaving in a perfectly acceptable manner (I, 172). In particular, Frau CarréLamadon is impressed by him, and when she becomes faint at the thought that he could have taken any of them by force (I, 172), there is a strong suggestion that it is not fear that causes this reaction, supported by Frau Loiseau's later bitter remark: "Am liebsten hätten Sie sich selbst zu diesem Offizier gelegt jawohl, ganz geil waren diese beiden schamlosen Frauenzimmer auf ihn [...]" $(\mathrm{I}, 190)^{45}$.

Indeed, as the play progresses, hypocrisy in matters of sexual morality becomes more and more visible. Hochwälder has made alterations to the Maupassant novella in this respect ${ }^{46}$, but the overall effect is the same, showing the paucity of genuine moral standards among the respectable travellers in comparison with those of the prostitute. Most importantly all the men make advances to Elisabeth (I, 157-160) ${ }^{47}$, yet all take great delight when Cornudet's approach is revealed (I, 184). Furthermore, when celebrating their victory, prior to Louis making his entrance, the couples flirt amongst themselves with Carré-Lamadon kissing the countess, while her husband does the same to Frau Carré-Lamadon (I, 183).

As her fellow travellers gradually reveal their own lack of moral scruples and selfishness during the play, Elisabeth stands out as the only truly principled among them. Even when she finally concedes and goes to the Prussian officer, she can do this in all conscience by knowing she must help the sick French soldiers.

Her fundamental decency and selflessness are reflected by Louis, who remains loyal to the heroine throughout the play. Unlike Elisabeth, however, he recognises the exploitative nature of the others and continually challenges their selfishness. On the two occasions when he is asked to help them he refuses, unprepared to help those who would do nothing to help another. He is appalled

45

The attraction Mme Carré-Lamadon feels toward the Prussian officer is also clear in Maupassant: "La gentille Mme Carré-Lamadon semblait même penser qu'à sa [Elisabeth's] place elle refuserait celu-là moins qu'un autre" [111].

46 The omission of the details about the sexual improprieties in the family histories of the Carré-Lamadons and de Brévilles has already been mentioned. Maupassant also refers to the nocturnal comings and goings amongst the passengers after they have celebrated Elisabeth's defeat [117].

47 In Maupassant, in fact, it is only Cornudet, the only single traveller amongst them, who makes advances. 
by the way they have treated Elisabeth on the journey to the inn (I, 144), and while he is prepared to make an extra effort for her, carrying the bags she left in the coach back through the snow to her, he refuses to go out and get food for the others, despite the offer of money (I, 129). He also refuses to intercede when it seems that Elisabeth may be going to murder the Prussian officer, although his life would also be in danger, and despite another offer of money (I, 191-192).

While Louis is used to generate additional dramatic tension, with the introduction of his knife as a potential murder weapon spoiling the general celebrations (I, 187-191) ${ }^{48}$, his main function, until the end, is to highlight further the moral inadequacies of the wealthy travellers. They clearly cannot comprehend behaviour that is motivated by anything but self-interest or greed. On the first occasion that he refuses to do their bidding, Graf de Bréville can only regretfully observe, while putting the proffered money away, that: "Krieg und Niederlage haben den biederen Sinn zerstört" (I, 150), while later, incensed that his money has been refused, Loiseau hurls the insult "Bestie!" at the unperturbed coachman (I, 192). Faced by someone who refuses to act from self-interest or for pecuniary gain they are at a loss as to what to do. Louis' disappointment that Elisabeth has given in and not killed the German (I, 192), is beyond their comprehension.

However, the biggest impact this introduced character has on the play, in comparison with the original novella, is the adaptation of the ending. When Louis makes his demands in the final act he is, yet again, misunderstood: they assume he wants money (I, 200), whereas he actual wants their food for Elisabeth. In doing so he allows Elisabeth, who had moments before seemed broken by the callousness of the others (I, 199), the opportunity to vent her anger on them, by rejecting their food and chasing them from the inn (I, 201202). Although she initially refuses to travel any further with the others, who have beaten a hasty retreat, Louis' suggestion she ride up top with him provides her with an honourable way to leave. As the triumphant Prussian military music fills the stage, the woman of conscience can exit with her head held high, arm in arm with the loyal coachman (I, 203).

So in Hochwälder's hands the Maupassant material, while maintaining much of the original story and some of its social criticism, communicates a comic moral message in which egotistical self-interest is exposed and the following of one's conscience is lauded, and allowed to triumph.

The conscience also triumphs in the end in Die Herberge, which is also a world of greed and self-interest, although here, as in Esther, the happy ending results more from fortuitous circumstance than anything else. The play is important for several reasons. Firstly, it marks a turning point in Hochwälder's work, acknowledged by the author himself:

Die Herberge, 1954/55 entstanden, markierte einen Wendepunkt in mei-

48 It is ironic, considering the situation France is in, that they choose to sing Offenbach, a German-born composer who achieved success in Paris. 
nem Leben und Wirken als Bühnenschriftsteller. Bis dahin wurde ich als Verfasser von Historiendramen eingestuft, eine veraltete Bezeichnung, die aber, da der Stempel nun einmal geprägt wurde, fleißig weiterverwendet wird wie so vieles, das sich in beschränkten Gehirnen festgesetzt hat. Um es bündig zu sagen: nach der Herberge, die bereits ort- und zeitlos ist, habe ich die Einkleidung meiner Themen in historische Kostüme endgültig aufgegeben, und was schwerer wiegt: meine bisherige Weltanschauung dazu. Da ich nun keineswegs bin, was man in Amerika einen "commercial writer" nennt, wenngleich ich meine Familie hauptberuflich von den Tantiemen meiner Theaterstücke ernähre, habe ich mich entschlossen, eher von Zeit zu Zeit die anstrengende Tätigkeit des Nichtstuns auszuüben, als auf den Brettern Dinge zu verfechten, an die ich nicht länger zu glauben vermag $^{49}$.

There can be no doubt that the play marks a clear move from historical dramas $^{50}$ and is an attempt at an allegorical tale, as suggested by the subtitle; Dramatische Legende in drei Akten. Certainly, Hochwälder rated the play very highly and in several interviews saw it as one of three plays, with Der öfentliche Ankläger and Das heilige Experiment, that would survive $\mathrm{him}^{51}$, and on occasion named it his best play ${ }^{52}$. He noted with pride that Albert Camus had wished to direct it before his untimely death ${ }^{53}$.

Besides holding an important pivotal position within the body of the dramatist's work, the play is also one of the clearest statements of the preeminence the author gives to the role of individual conscience ${ }^{54}$.

In Die Herberge daily life is disrupted by the arrival of two outsiders, Berullis and his driver, Andusz. Confined to the inn for the night these travellers are forced to confront shadows from a past ${ }^{55}$ they are desperate to conceal: "Nie49 Hochwälder, Im Wechsel der Zeit, 94-95.

50 Although it should be noted that Hochwälder returned to historical dramas in some of his final plays. Cf Die Prinzessin von Chimay and Die Bürgschaft.

51 Anonym, "Ehrenring für Fritz Hochwälder", Die Bühne [Wien], Nr. 169, Okt. 1972; haku, "Ein "verdammter Moralist"”, Salzburger Volksblatt, 30. Juli 1975; H. B., "... ein verdammter Moralist", Salzburger Volkszeitung, 30. Juli 1975.

52 Walter Zitzenbacher, "Porträt der Woche", Kleine Zeitung [Graz], 8. April 1967; Walter Scheiner, "... noch Asche echten Theaters ist produktiv", Vorarlberger Nachrichten [Bregenz], 3. Aug. 1976; Gerwald Rainer, "Ohne Glas Wasser", Neue Vorarlberger Tageszeitung [Bregenz], 4. Aug. 1976.

53 Zitzenbacher, "Porträt der Woche".

${ }^{54} \mathrm{Vital}$ to an understanding of this is the debate that occurs at the end of the play between the characters of the magistrate, Smalejus, and the vagrant, Schimke, in which the whole question of justice and individual conscience is discussed, from quite different perspectives [see Chapter 4].

55 Hochwälder had already explored the idea of an individual being unable to escape his past in "Der Prozess" and returned to it again in Der Unschuldige, Der Himbeerpflïcker, Der Befehl, and Die Prinzessin von Chimay. 
mand darf wissen, was längst begraben ist, niemand darf es erfahren!" (II, 81). However, as the magistrate, Smalejus, takes control of an investigation into missing gold, the play takes on all the aspects of a courtroom drama ${ }^{56}$, and, on this one exceptional night the truth will be revealed. As the story unfolds the notions of justice and ownership come under scrutiny and the oft-repeated words "Jedem das Seine", (II, 90, 103, 104) take on a significance that none of the characters could anticipate at the outset.

Greed and self-interest dominate the motivation of most of the characters in the play, with the exception of Smalejus and Schimke, and the murderer, Andusz. While Andusz, like his master, has a dark secret that will be exposed during the course of the play, the murder he committed twenty-five years previously, was a result not of greed but of uncontrollable desires ${ }^{57}$.

Central to the action of the play is Jon Berullis. A successful businessman, he labels himself a "Makler" (II, 79), but is more accurately described by Kavolius, a character who proves himself expert in such matters, as a "Wucherer" (II, 94). Certainly, he has acquired his wealth by extremely dubious means, but then, in this society, it is money rather than conduct by which one is judged: "Es ist keine Gnade in der Welt, drum läuft alles dem Gold nach. Man wird reich, sehr reich... wie man begonnen hat, wer fragt danach?" (II, 83-84). This has already been confirmed by Kavolius, who observes with respect his guest's reputation as "der unbarmherzige Berullis" (II, 79). Yet Berullis would like to believe that beneath it all he is a good man corrupted by society:

BERULLIS: [...] Kann man immer so sein, wie man von Natur ist? KAVOLIUS: Da hast du recht.

BERULLIS: Ich sag dir: man kann nicht! [...] Alles an mir ist Gold! Den Unbarmherzigen nennt man mich. Den Goldenen sollte man mich nennen, wozu ein zweites Wort? Gold kennt keine Gnade - Und doch bin ich von Natur ein guter Mensch. (II, 83)

His philosophy is simple and brutal: "[...] Drückst du nicht, drückt man dich; würgst du nicht, würgt man dich; schlägst du nicht, schlägt man dich!" (II, 83).

However, he must concede that wealth and power cannot acquire everything: "Und doch bleibt Sehnsucht nach dem, was durch Gold nicht erworben wird [...] Jugend, Reinheit, Schönheit - und Zeit genug für einen alten Mann!" (II, 84), and he ruefully observes to Andusz:

56 Hochwälder was well aware of the dramatic effectiveness of legal investigation and cross examination, and frequently uses similar techniques in his plays, cf. Das heilige Experiment, Meier Helmbrecht, Der offentliche Ankläger, Donadieu, "Holokaust", Die Prinzessin von Chimay.

57 In this struggle against his dark side he has much in common with the protagonists of "Jehr" and Der Befehl, and the villain of "Der Prozess". There are also important thematic links with 1003 and Lazaretti oder Der Säbeltiger.

58

Cf. II, 116. 
Was taugt Gehorsam, Gewalt? - Gehorcht der Knecht nicht, wird er gezüchtigt, das nächste Mal gehorcht er. - Fordert einer zurück, was sein ist, und weist keine Quittung vor, was hindert mich, Gewalt gegen ihn zu brauchen, was war er vertrauensselig, bin ich es je gewesen? - Doch beim Mädchen? Kann Gewalt, Gehorsam - Liebe erzwingen? Nichts in der Welt kann Liebe erzwingen...

(II, 84)

Nevertheless, if money cannot buy him love, Berullis still shows few scruples when it comes to his wealth and is very distrustful when he arrives at the inn (II, 74-79). Yet he is surprised when others show as little trust in him, and there is heavy dramatic irony in his question to a wary Staschia: "Seh ich aus wie ein Dieb?" (II, 76), since it will soon be confirmed that this is exactly what he is.

Indeed, this first act, in typical Hochwälder fashion, is full of hints about events to come ${ }^{59}$, nowhere more so than in the exchange between landlord and guest once the gold has been stolen. Kavolius, who doubts that the money ever existed, warns Berullis what may happen:

KAVOLIUS: [...] Überleg es dir gut, Herr. Noch ist es Zeit. Wenn der Amtmann hier ist, kommt die Wahrheit auf.

BERULLIS: Was will ich anderes als die Wahrheit?! [...]

KAVOLIUS leise: Sieh zu, daß du es nicht bereust [...]

BERULLIS: Bereuen... was hab ich zu bereuen? Ist nicht mein Gold verschwunden? Ist es nicht mein Gold? [...] Noch in dieser Nacht wird Gerechtigkeit sein - oder ich bin nicht mehr Jon Berullis

(II, 89)

Typical of Hochwälder, characters inadvertently predict the outcome of the play, for the truth will be revealed and justice will be done, and the gold Berullis stole from the father years before will return to the rightful heir.

As the play progresses, it becomes increasingly clear just what sort of man Berullis is. In proving to the magistrate that the stolen gold actually existed, with a letter from a reluctant borrower, he is forced to reveal that he makes his money by usury and the exploitation of others (II, 99). Smalejus is well aware that Berullis' business practices give him no right to demand justice:

Gäbe es Gerechtigkeit, dann stünde es nicht gut um dich, Jon Berullis. Ich habe den Brief gelesen: die Söhne des Miks Wiespatis werden dich verfluchen, du frißt ihr Erbe, wohl bekomm's, schneidiger Kaufmann! - Wer schützt die Schwachen, Erpreßten, Übervorteilten, wer legt dem Wucherer das Handwerk? Wo ist Gerechtigkeit, die du anrufst?

(II, 102)

Later it is revealed how Berullis has exploited Andusz, treating him as a slave for twenty-five years, providing just food and clothing, but no wages (II, 110112).

59

See above regarding "Der liebe Augustin". 
But despite a lifetime spent exploiting others, as the night progresses, Berullis comes to believe that one cannot indefinitely escape the consequences of one's actions. As it becomes clear that the truth must come out, he confesses to the original theft of the gold:

Wenn nichts ist, nichts im Himmel, nichts auf Erden, nichts in uns; wenn jeder lebt, wie es ihm gefällt und stirbt ohne Vergeltung - wer ruft (schlägt an die Brust) hier! hier! -: 'Bezahl die Zeche, Mensch!'? Ist da nicht einer, der alle Schuld aufschreibt und einfordert zur Zeit, geschieht es nicht, daß jedem das Seine wird, frühmorgens, in der Herberge? Was nützt es, zu schweigen, was hilft es, die Stimme zu ersticken Jahr um Jahr, wird sie nicht dennoch laut, fordert sie nicht Rechenschaft? [...] Nicht du Minjotai, bist der Dieb. Ich bin es. [...] Ich wurde reich, gefürchtet, angesehn - und heut, wer bin ich? Was bleibt mir? Besitzt du nicht, was Gold niemals erwirbt, nimmst du mir nicht das Mädchen? Bin ich nicht in Wahrheit der Ärmste, fremd da und dort, einsam, ausgestoßen überall?

(II, 132-133)

Under the peculiar circumstances of this one night at the inn, and with no small element of self-pity, Berullis seems shaken enough to want to repent and change his ways, wishing to leave his old life and go with Schimke:

Gern würd ich dir folgen, in die Fremde ziehn mit dir... Kann ich es? Wer läßt Haus und Geschäft und ändert sein Leben mit Sechzig? - Und doch schreit es - (schlägt sich an die Brust) hier! hier! -: 'Ändere dich, Jon Berullis! Wie lang bleibt dir noch Zeit, zehn Jahre, wenn's hoch kommt zwanzig - und dann?'

However, he is not prepared to make too great a sacrifice, "Ist nicht Elend genug in der Welt, das der Reiche lindern kann und fährt nicht schlecht dabei?" (II, 136). Rather than accept Schimke's humble existence, he tries to tempt the pilgrim to come and live with him and alleviate the loneliness he will now face without Andusz.

The extent to which the night's events will have any long-term effect on the usurer quickly becomes apparent after Schimke politely declines his offer. Offended, Berullis leaves angrily declaring he is satisfied with his lot. As Schimke observes, the events of the night will have no lasting impact on Berullis: "... da erkennt der Mensch, daß alles ist wie Ruf und Widerhall - und er geht hin und vergißt, als wär nichts gewesen..." (II, 137). Having overcome his moment of weakness when the voice of his conscience spoke loudest, the usurer is again prepared to exploit his fellow man to his own advantage.

While Berullis is the main villain of the piece, he has much in common with most other characters in the play, who are just as ready to sacrifice moral scruples to the dictates of self-interest, sharing his moral shortcomings and to some extent guilt ${ }^{60}$. Indeed, much of the humour in the play comes from the 
way Hochwälder has lesser figures mirror the behaviour of the central characters.

The innkeeper, Kavolius, has the most in common with the wealthy usurer. It has already been noted that he admires Berullis for the reputation he has for making money from exploiting others (II, 79), an endeavour he also actively pursues. When the play opens, he is away from the inn collecting debts, something for which Simkala reveals he is well known (II, 67), as is his lack of generosity: "[...] der beherbergt niemanden ohne Geld, da ist er wie der Teufel". (II, 68) This he later confirms when he refuses to give Jurgis any food: "In meiner Herberge wird nichts geschenkt! Bezahlt muß alles sein jedes Krümchen Brot!" (II, 115) Like his role model, Berullis, he is deeply distrustful of strangers, until he sees the colour of their money (II, 78-79), and like his guest sees deception at every turn, particularly when the gold goes missing, even going so far as to question its very existence (II, 94). At the end of the play, the evening's events have had no impact on his insatiable avarice, and he has no hesitation in giving his daughter away in exchange for Jurgis' gold, although this would leave his future son-in-law again poor and with few prospects. With his new-found wealth, Kavolius spends even less time than Berullis in contemplating helping others:

Das Gold - mein Gold! Was fang ich an? Die Herberge ausbessern, vom Keller bis zum Dach, die Treppe? Was nimmt man sich nicht alles vor! Wer vorüberfährt, kehrt nicht ein; wer einkehren muß, ist mit der Unterkunft zufrieden; wer die Treppe steigt, nimmt sich in acht; wen Un-geziefer plagt, der kratzt sich; wem's hier zu schmutzig ist, wäscht sich draußen am Brunnen. Die Herberge bleibt, wie sie ist, keinen Kreuzer wend ich dafür auf! (Schließt die Kassette, nimmt sie unter den Arm.) Ich weiß, was ich anfang: Ich wander nicht mehr mit der Rechnung, Freitag abends, ich leih auf Zinsen, aus tausend mach ich hunderttausend, und wer mir nicht zum Termin zahlt, den klag ich ein, den zieh ich vor Gericht! Ihr Schuldner, wartet - euch werd ich karniefeln!

(II, 135)

Clearly Kavolius is another Berullis in the making.

If Kavolius is a minor exploiter in the shadow of Berullis then Simkala, the local gendarm, in his relentless insistence on carrying out the letter of the law in the name of order, shares much with the magistrate, and highlights the fundamental inhumanity of Smalejus' position. He first appears on the trail of a vagrant whom he wishes to see away from the village before midnight so that the village is not legally obliged to feed him through the winter. With sentiments that will be later echoed by Jurgis and Smalejus (II, 92, 102-103), he has little faith in God: "Wieviel Menschen kriechen auf der Erde herum? Ich weiß es nicht, aber Gott weiß es, wohin käm er, wenn er sich um jeden einzelnen kümmern möcht?" (II, 68) Therefore, he pursues his heartless task in the name of doing his duty, noting that: "Vom Mitleid steht nichts im Gesetz" (II, 68).

${ }^{60}$ Cf. Schmitt, "The Theme of Responsibility [...]", 87 . 
When the coffin maker Smelte hears of the vagrant, and ascertains that should the hapless man freeze to death in the woods, the village would be obliged to pay for the burial, his hopes of some desperately needed business are raised. An argument develops between the two, with Smelte hoping the tramp will die in the vicinity and provide him with business, while Simkala hopes he dies elsewhere. Their complete lack of humanity toward a fellow man leaves the sympathetic Staschia wondering aloud: "Was seid ihr für Menschen..." (II, 69).

Simkala's insistence on following the law and official protocol to the letter is humorously highlighted in a later scene, when he questions Kavolius about the missing gold. Despite having already been told what has happened, to the frustration of the landlord, the whole story must be repeated "officially" to satisfy the pedantic gendarm (II, 94-96). If this conversation holds up Simkala to gentle ridicule, the potential brutality of his office is exposed when he is ordered to question Smelte, and but for Jurgis' intervention, would have beaten a confession out of the hapless vagrant (II, 127).

As a minor character, Simkala serves to demonstrate the inhumanity of officialdom in Die Herberge. But even the victims in this society show scant regard for others. While the gendarm is able to hide his behaviour behind the dictates of his office, the coffin maker, Smelte, recognises just how rotten the world is, but refuses to take any responsibility for either his own position, or the contribution his behaviour makes to the general injustice around him. His main aim in the opening scenes is to drink seven glasses of schnapps in order to escape the world for an alcoholic heaven and fly home like an angel (II, 6768 ). He sees the world as being totally against him, and, failing to see that he only profits from others' misfortune, paints a sorry picture of his predicament:

Dem nichts gebührt, der sitzt im Fett, und der Bedürftige geht leer aus. In Dragoschan war Typhus, und mich haben sie nicht geholt, Ungelernte haben sie genommen, was ist geschehn, die Särge sind ihnen aus dem Leim gegangen. Wär hier ein Sargmacher, der von Haus aus wohlhabend ist - ich möcht wetten: der Landstreicher wär vor der Herberge erfroren, nur, damit der bekommt, der hat! Aber weil ich es bin, wird er sich zehn Meilen weit durch den Wald schleppen: so wird der Mensch, der von Natur aus gut ist, böse. Ich bin ohnehin noch viel zu gut, ich sollt rauben und stehlen, damit es die Menschheit sieht. Aber was hätt ich davon, dazu muß man geboren sein, mich möchten sie gleich packen und aufhängen! Und da heißt es: Jedem das Seine! Wer's glaubt, wird selig!

(II, 70-71)

The echo of Berullis' self-pity and self-justification is not difficult to discern and the motif of "Jedem das Seine" reappears, meaning quite different things to the different characters.

Throughout the course of the play Smelte vacillates from hope to despair at the prospect of a thief to hang, which would provide work for him and the means to buy his seven schnapps. Comical though his efforts to ensure a 
coffin is needed are, providing dramatic relief from the tension of the investigation, he, like those around him, hopes to profit from another's misfortune. Therefore at the start of the second act, having heard that there is a thief, Smelte is elated and full of re-found faith:

Gott tut ein Wunder, wenn die Not am größten ist. Ich war drauf und dran, ihn zu leugnen, aber es gibt ihn, der Beweis ist geliefert! - Wo steckt er, wo liegt er, wo sitzt er? Ich muß es wissen, so ein Särglein macht sich nicht von selbst.

Eager to start work he annoys both Simkala (II, 96-97) and Smalejus (II, 104105), attempts to bring Berullis round from his second thoughts about pursuing the thief (II, 118), only to endure much uncertainty in the third act as the truth finally comes out. However, he can eventually leave the inn to start work on Andusz' coffin, content that he has seen a miracle and still thinking only of himself (II, 134).

Even the positive characters Jurgis and Staschia, are tempted to put selfinterest ahead of what they know to be right and become involved in theft and deceit. Staschia is a good and pure character, reminiscent of other female characters such as Rouzha in Lazaretti oder Der Säbeltiger and Maria in "Der liebe Augustin", and like them remains an unrounded, one-dimensional voice of humanity. She rejects the callousness of Smelte and Simkala (II, 69), and perhaps less credibly, shows pity toward Andusz, who has nearly throttled her, when she promises not to tell what he has done (II, 81). Such is the effect her personality has on others that Berullis cannot believe she had anything to do with the theft (II, 89), and wonders aloud what influence she might have had on him, had he met her in his youth (II, 113).

But even the noble Staschia is drawn into a web of deceit, attempting to hide what Andusz has done, and becoming Jurgis' accomplice in the theft of the gold, albeit against her better judgement. Of course, lying is not her forte, and she nearly gives herself away to Smelte, at the start of Act II, by, having already claimed there is no thief, readily taking up his suggestion that the thief must be wealthy, since the poor only get away with small amounts (II, 93). Furthermore, she does not join the others in looking for the gold, when told to by Simkala (II, 102), and almost reveals to Smalejus that Andusz did indeed move from his seat, long enough for the gold to be stolen (II, 109). Her loyalty to Jurgis continues to the end, when desperate to protect him, she claims to be the thief herself (II, 128). It is only when all else has failed that she is forced to reveal what Andusz has done (II, 129).

Jurgis' path to crime is one of desperation, born from his love of Staschia. Although the young couple love one another, their future is bleak as long as Jurgis remains an impoverished woodsman. Together they dream that he might regain the wealth his dead father once had, and cling to the hope of gold given by a gypsy fortune-teller, in another typical Hochwälderian prophesy (II, 7273). When gold does indeed lie before him, Jurgis takes the opportunity to 
steal it as Andusz is distracted by Staschia, after first ensuring that she is safe (II, 81).

Later he justifies his actions with a familiar argument heard elsewhere in the play: "Wer das Seine nimmt, ist kein Dieb. Von Anfang an hab ich gewußt: Gold steht mir zu! Hätt ich den Augenblick versäumen sollen?" (II, 90). Once again there is irony in the words, for without Jurgis, or the audience knowing, he has indeed taken what is rightfully his. He convinces Staschia to go along with his plans, since it is their only chance at happiness and because he is convinced that no one innocent will be condemned. To her concern that God may punish them, ${ }^{61}$ he echoes the cynicism of both Simkala and Smalejus:

Gott läßt alles zu. Täglich kommen Tausende um, Unschuldige, Schuldige, wen kümmert es? Wer schützt die Guten vor den Bösen, die Armen vor den Reichen? Wer deckt Verbrechen auf, die längst vergessen sind? Wer verfolgt den Dieb, der meinen Vater bestohlen hat, wer straft den Mörder meiner Mutter? Wer zwingt dich zur Braut eines stumpfen Bauern, wer heißt mich, arm zu bleiben, wie ich bin? Liegt unser Schicksal nicht in unserer Hand? Wer hält uns auf, zu tun, was uns nützt? Ob einer am Galgen endet oder im Straßengraben, eins ist nicht schlimmer als das andere - das glaube ich!

$(\text { II, } 92)^{62}$

However, despite such cynicism, Jurgis shows himself to be fundamentally decent, when toward the end, he is asked to hold Schimke so he may be beaten (II, 128). What follows is an amusing case of confession and counterconfession as Jurgis and Staschia try to protect one another and Kavolius, Berullis, Smelte and Simkala all get involved.

Once the full truth about the theft has been revealed, Jurgis suddenly finds himself legitimately in possession of the gold and in a position to avenge his father by demanding punishment for Berullis. However, the young man remains true to his conscience and remembers his earlier words, rejecting the view of justice propounded by Simkala and Smalejus:

Wie hab ich gesprochen, Staschia? Täglich kommen Tausende um, Unschuldige, Schuldige, niemanden kümmert es... Wer straft den Dieb, verfolgt den Mörder, wer deckt Verbrechen auf, die längst vergessen sind... Und heut? Und jetzt? Schleicht sich nicht in unser Herz Gerechtigkeit wie ein Dieb in der Nacht? Was braucht es Strafe, ist es nicht schrecklich, Rechenschaft abzulegen? ( $Z u$ Smalejus:) Wenn alles zurückkäm und blickte uns an, Tag für Tag, Nacht um Nacht, wie sollten wir weiter-

61 It is significant that only the virtuous Staschia and the mystical Schimke have any real faith in a higher order, highlighting the moral corruption of the other characters.

62 Later Berullis answers the questions Jurgis raises, when he himself is temporarily convinced that one cannot indefinitely escape one's actions. Using the example of the Seventeenth Century Ukrainian Hetman who instigated pogroms against Jews and Catholics he argues: "Als Chmelnitzki kam und die Juden metzelte, wer sonderte die Wucherer von den Heiligen, wo blieb Gerechtigkeit? Wer streitet Gerechtigkeit ab, wohnt sie nicht in der Frage? Wo ist Chmelnitzki? Wo modert sein Gebein? [...]" (II, 132). 
leben? Vergessen, Amtmann, vergessen! - Nichts war. Nichts ist geschehn. Ich klage niemanden an. Ich klage nicht.

Furthermore, Jurgis rids himself of the danger material possessions might pose by offering his newly acquired wealth for Staschia's hand (II, 134135). ${ }^{63}$

So, at the end of the play, having yielded to temptation, Jurgis and Staschia have redeemed themselves. However, the events of the night have not led to changes in attitude in the other characters and the issue of whether the world can become a better place remains a subject for debate between Smalejus and Schimke.

While greed and selfishness have been portrayed as a general social trait in the plays discussed so far, in several dramas Hochwälder prefers to focus more exclusively on individual characters. Such figures choose to put their personal interests ahead of those around them, often in the misguided belief that material profit will lead to their happiness, but inevitably their wrong-doing has unexpected results. Jurgis has been so motivated in Die Herberge, believing that theft can offer a future for him and Staschia, yet he could not have expected such results from his actions. The results are not always so fortuitous as is the case in the early radio play "Trommler".

This drama is based on an actual event ${ }^{64}$ in which a soldier, presumed killed in the war, finally returns home many years later. No one, including his parents, recognizes him and before his identity is revealed he is murdered by his mother for the large sum of money he has brought back with him. ${ }^{65}$ "Trommler" is an unsatisfactory, immature work which struggles under the constraints of a heavy Expressionist influence and the subsequent unconvincing development of characters. The figure of Franz Trommler is central to the action for most of the first half of the play, but by the end has been reduced to a passive victim as interest switches to the actions of his parents. The thematic focus of the play shifts markedly from an initial concern with the isolation of individuals from the wider society to the terrible crime of the parents.

At first, attention centres on Trommler's confusion and despair when he returns to his home village to find that he is a forgotten and unrecognised person. This anguish is heightened by his parents' failure to recognise him, and he is shocked how twisted they have become. ${ }^{66}$ As a result of this, he does not reveal his identity to them, but agrees to sleep in the barn that night, before leaving for a much needed drink at the local tavern. It is only now that any genuine dramatic tension is generated, as Hochwälder juxtaposes events at

63 The fact that he has voluntarily returned to the poverty that threatened their future at the start of the play is not addressed!

64 The original newspaper story is reproduced at the end of the typescript (T, 96-97).

65 The theme of failing to recognize someone close to oneself, both in their physical appearance and their true nature is a recurrent theme in Hochwälder's work [see Chapter 5]. 66

"Ich sollt der Sohn von der giftigen Alten sein?" (T, 35). 
the house with those in the pub and the story races toward its tragic conclusion. Here, Hochwälder shows the theatrical skills put to better effect in later dramas such as Der öffentliche Ankläger ${ }^{67}$

The motif of self-interest as the motivation for crime dominates the latter scenes of the play. The mother, consumed by her own grief over her lost son, has become obsessed with finding him, and to this end she will stop at nothing. In this Hochwälder adds a new element to the original story by making her motivation to kill Trommler not purely one of simple greed: she wishes to use the money to fund the search for her son, convinced he is still alive ( $\mathrm{T}, 51-53)$. In this she can be seen as an early forerunner of characters who insist that the ends justify the means, ${ }^{68}$ and she shares the mistaken belief shown by Jurgis in Die Herberge and Gustave in Der verschwundene Mond that money can be used to acquire happiness. Such is her grief for her son that she elevates her own need above that of her hapless guest, and ignores the pleas to her conscience by her husband.

While the mother is completely hardened in her resolve and is totally fixated on the money, the father recognises that nothing can justify murder and, with dramatic irony, tells her that were their son alive he would be just such an unfortunate individual as their guest $(\mathrm{T}, 53)$. However, his weak attempt to dissuade her ( $T, 51-53)$ quickly fails and he attempts to distance himself from the crime, wanting no part of it: "Dass du's weisst: ich bin nicht schuld!" (T, 59). He chooses to turn his back on the situation by going to the tavern to drink, where, too late, he learns the truth about Trommler's identity. Nevertheless, he is clearly an accomplice and agrees that he will use the money to look for their son. By attempting to wash his hands of the crime, while doing nothing to stop it, the father can also be seen as a prototype for later Hochwälder characters. ${ }^{69} \mathrm{He}$ too will not escape the terrible consequences of refusing to act on his conscience.

In "Kaufmann und Künstler", the self-interest of the protagonist does not lead to any criminal activity, but does result in behaviour that pays scant regard to others, and as such might have provided material as equally suited to a tragedy as to the comedy in which it appears.

There has been speculation that the play was written in $1935,{ }^{70}$ Hochwälder himself was unsure ${ }^{71}$, but it would seem more likely, on the evidence of the 67 Murphy, 28.

${ }^{68}$ The same justification is used by Querini and Miura for the injustice they contribute to in Das heilige Experiment, by the Talliens to vindicate killing Fouquier in Der öffentliche Ankläger, and by Heloris in Die Bürgschaft to justify the use of force.

${ }^{69}$ Cf. the Grenzwächter in Der Flïchtling and Meier Helmbrecht in the play of the same name.

70 Bortenschlager, Der Dramatiker Fritz, Hochwälder, 31; Hermann Böhm, Fritz Hochwälder. Ausstellung der Wiener Stadt- und Landesbibliothek und des Österreichischen Kulturzentrums im Palais Palffy. 15. Mai bis 30. Juni 1991 [Ausstellungskatalog], Hrsg. Herwig Würtz (Wien: Wiener Stadt- und Landesbibliothek, 1991), 25 - surprisingly the play is absent from the chronology of works at the end of the catalogue [70-71]. 
text, that it was written later, in either 1936 or $1937^{72}$. That aside, it is the most assured of all the early unpublished works, showing a deftness of touch and considerable comic skill, even if thematically it remains insubstantial. Wilhelm Bortenschlager's regret that the play never made the stage is understandable ${ }^{73}$, although in his enthusiasm he reads too much into the text:

Das harmlos erscheinende Boulevardstück - bestes Unterhaltungstheater übrigens, an dem es im deutschen Sprachraum schon immer gemangelt hat, sieht man von Einzelpersönlichkeiten wie Alexander Lernet-Holenia $\mathrm{ab}$ - mit seiner Situations- und Charakterkomik, das meiner Ansicht nach weit über Feydeaus heute wieder aktualisierter Klamaukkomik steht, hat ein ernstes Thema zum Vorwurf: Talent und Genie, Glaube an das Talent und Enttäuschung, Schein und Wirklichkeit, Aufbau eines Malers durch einen Mäzen und durch die Presse und dann der wiederum durch die Presse eingeleitete Absturz ${ }^{74}$.

In fact, the play is less concerned with artistic ability than Bortenschlager would have one believe, except perhaps to show that true art cannot be produced simply to satisfy a demand for recognition or a desire for profit. The quality of Lutmer's work, both the earlier "masterpieces" and the later disappointments, remains unchallenged, as does Bohl's ability to judge their merits. Nor is the play concerned with media manipulations of reputations, indeed it is hard to see from where Bortenschlager draws his conclusion about a "durch die Presse eingeleitete[n] Absturz", since Lutmer cancels his later exhibition before the public or press can see the paintings.

The focus of "Kaufmann und Kuenstler" is firmly on the behaviour of its protagonist Gerhard Lutmer, who dominates every scene in the play. He foolishly falls hostage to his own ego, inflated by the opinions of others, since he is clearly a very poor judge of his own abilities. Flattered by the views of experts, he pursues his own ambitions regardless of the effect it has on those close to him. Fortunately, as is befitting a comedy, he recognizes the error of his ways before it is too late, allowing a happy resolution.

71 Bortenschlager, Der Dramatiker Fritz Hochwälder, 31 .

72

Bortenschlager seems to base his Entstehungszeit on the incorrect assumption that the action in Acts I and II takes place ten years after the Vorspiel [Der Dramatiker Fritz Hochwälder, 32, 34], which quite specifically takes place in $1924(\mathrm{KuK}, 3)$. However, while the art expert and architect Bohl estimates the rediscovered pictures by Lutmer to be approximately ten years old $(\mathrm{KuK}, 19)$, Lutmer himself reveals that he has been working for the business for eleven years $(\mathrm{KuK}, 24)$ and that it is twelve years since he walked out on Irene $(\mathrm{KuK}, 33)$, thus placing the action in 1936. Of course Hochwälder, if the play was indeed written in 1935, may have deliberately set the action in the future, but there seems no reason for this. The date of 1936 or 1937 also assumes that Bortenschlager, and presumably Hochwälder, with whom he had contact, were indeed correct in believing it was written before Eulenspiegels Erdreich.

73 Bortenschlager, Der Dramatiker Fritz Hochwälder, 35.

74 Bortenschlager, Der Dramatiker Fritz Hochwälder, 33-34 
In the Vorspiel the hapless Lutmer has already been imprisoned for a month in a loft, where he is forced to paint by his girlfriend, Irene. She has recognized his talent, but to stop him wasting it and for his own good, has felt it necessary to lock him in to force him to use it (KuK, 4). Unfortunately, Lutmer does not share her enthusiasm and longs to escape, all the more so when his friend, Ernst, invites him to the première of Georg Kaiser's Gas $(\mathrm{KuK}, 5)^{75}$, which is expected to be controversial. This leads to a confrontation with Irene, and Lutmer shows his own disregard for his work by threatening to destroy his pictures, repenting only when he has reduced Irene to tears $(\mathrm{KuK}, 10)^{76}$. The low value he places on his work is then confirmed when, making use of the distraction provided by the appearance of removal men to escape, he disposes of his paintings in an empty trunk, without a second thought for them or Irene (KuK, 13).

Lutmer really cannot see his own talent, as he reveals with a telling remark in the Vorspiel: "Jetzt sag mir einmal, Irene, woher weisst $\mathrm{Du}^{77}$ das eigentlich, ich meine, von meiner grossen Genialität. - Ich selbst spür sie nämlich nicht, ehrlich gesagt ... Ich müsst mir's erst einreden" (KuK, 11). Later his return to painting is inspired by the opinions of others, rather than any need for artistic expression. He certainly does not have Irene's view of artistic genius or what it means to become someone:

LUTMER: (Sag [sic] mal, wass [sic] ist denn das eigentlich - etwas werden! Berühmt und reich, nicht wahr?

IRENE: (schüttelt den Kopf)

LUTMER: So stte [sic] ich es mir wenigstens vor.

IRENE: Dann hast Du eine falsche Vorstellung davon, mein Lieber. Ich werde Dir sagen, was es ist. - Nichts andres als Arbeit. Arbeit! Arbeit! - Und das Bewusstsein, zu arbeiten, ununterbrochen - kurz, das Gegenteil von Zerstreuung...

LUTMER: Sieht nicht sehr verlockend aus, muss ich sagen. - Uebrigens sich zu Tode rackern kann jeder Deichgräber oder Strassenkehrer.

IRENE: Gewiss, es ist auck [sic] die gleiche Plage. -Aber ich glaube, es ist ein Unterschied, ob man ein fanatischer Strassenkehrer oder ein grosser Maler ist!

LUTMER: Aber ich möchte doch was haben vom Leben, ich will nicht so arm bleiben, wie jetzt, und mich von Dir aushalten. [sic] lassen. Ich möchte mich gut kleiden, und überhaupt ordentlich leben und arbeiten, aber nicht allein, kontemplativ, vestehst Du - sondern mit Menschen, unter Menschen, immer lebendig, in der Menge, im Kollektiv, wenn Du's so willst. - Und dann müsstest Du schöne

75 Kaiser was later to befriend Hochwälder in exile in Switzerland and encourage the young Austrian in his writing career.

76 Lutmer seems only able to consider the feelings of others when they are revealed to his face, and he shows similar behaviour when later asked for help by his wife (KuK, 32).

77 Hochwälder consistently begins second person pronouns with capitals in the typescript. 
Twelve years later, Lutmer has worked himself up to be in charge, with his wife, of the company Widhalm-Lutmer, and seems to thrive on the hustle and bustle of business (KuK, 15-18). He has put art so far behind him that his apartment contains no pictures, and he is horrified by the prospect of them being incorporated into the renovations planned by architect Bohl (KuK, 19), reaffirming that he knows nothing, nor cares, about art. Bohl, however, has discovered Lutmer's old pictures and recognizes them as works of genius. It is this recognition that throws Lutmer into confusion (KuK, 20), which increases when he learns that Bohl was the discoverer of Kokoschka (KuK, $21)$, and reads the newspaper article on the work (KuK, 21). He telephones his friend Dr. Gross, who also understands art and who confirms Bohl's opinion, and more importantly, tells Lutmer that the paintings will be worth a fortune in a few years $(\mathrm{KuK}, 23)$. Convinced now of his own genius, and believing he can now become someone and have a pleasant lifestyle, he immediately decides to start painting again, with no regard for the effect on the company, nor his wife (KuK, 23-25).

Two months later Lutmer must face up to the fact that his work is so lousy even he can see it, an opinion confirmed by Gross. He must recognize that art cannot simply be produced: "Das ist ein Dreck! Das ist der letzte Dreck! Das ist eine blöde, unfertige technische Angelegenheit, eine kalte Mache, ohne Zorn, ohne Leben [...]" (KuK, 27).

However, he sees sudden salvation with the arrival of a telegram from Irene, saying she wishes to see him $(\mathrm{KuK}, 28)$. Unbeknown to Lutmer, she is bringing a sick child to a doctor in town, and having read about him in the papers has thought to visit him (KuK, 36-37). He, so wrapped up in his own importance as he is, presumes she must want to devote herself again to his artistic endeavours.

His selfishness is further demonstrated by the visit of his deserted wife, Luise, who has come, not to ask for anything for herself, but to ask Lutmer to help save the business which has gone downhill since he left. In his haste to get rid of her before Irene arrives, he reluctantly agrees to go into the office the next day, assures her that there is no other woman, and then must give the flowers intended for Irene to Luise to support this lie (KuK, 32).

However, when Irene finally appears, Lutmer quickly has his last illusions shattered. She is more interested in hearing about the famous Bohl than seeing his newest pictures $(\mathrm{KuK}, 35)$, and soon corrects his arrogant assumptions about her life:

LTMER [sic]: [...] Ich brauche Dich - und Du kannst doch auch nicht glücklich gewesen sein...

IRENE: Wer sagt dir das!... Wennn [sic] Du schon das Vergangene heraufbeschwörst, gut, dann werde ich Dir alles sagen, wie's ist... In der ersten Zeit war's schon arg. Ich war wie vor den Kopf geschlagen. 
Warum, das begreif ich heut' eigentlich nicht... Aber dann habe ich gesehen, das Durchschnittsleben, das hat doch viel voraus vor dem unsteten Künstlerrummel, nicht wahr... das hab ich nun eingesehn, und ausserdem für eine Frau... nein Gerhard, ich begreif' nicht mehr, was damals in mir war... Das ist abgestorben, und ich bin nicht traurig darüber. - Aber wir führen ja richtige Friedhofsgespräche... geh, sei ein bisschen lustig!... Oder freust Du Dich nicht, dass Du mich wieder einmal siehst...

LUTMER: Irene! Um Gotteswillen - das ist nicht die Wahrheit! Das ist nicht die Wahrheit! So hast Du nicht gelebt. Das ist gelogen Pfui!... Jetzt sag nur noch, jetzt sag nur noch, (er kommt in lächerliches Stammeln)... jetzt sag nur noch, dass Du wieder fortgehst... jetzt sag nur noch, dass Du wieder fortgehst!

IRENE: Freilich! - Was hast Du denn geglaubt?

LUTMER: Aber Du musst doch bei mir bleiben! Du versäumst doch Dein Leben! Du bringst Dich ja um!IRENE: Geh,Gerhard, brüll nicht so über die Jahre sind wir ja beide hinaus... Ich kann Dir ja sagen, wie ich leb'... dann wirst Du sehen, dass es grad das Gegenteil ist.

LUTMER: Nein, Nein! Nein! Du darfst keine alte Jungfer werden!

IRENE: Aber Gerhard! - Wenn Dich mein Mann hören würde, der würde lachen!

$(\mathrm{KuK}, 36)$

Lutmer is forced to recognize that his dream of becoming an artist has been in vain; it is, as Irene has made clear, a chapter in his past $(\mathrm{KuK}, 38)$.

All that remains to round off the comedy is a satisfactory denouement. Keeping his promise to visit the office the next day, Lutmer at first observes the incompetence of his successor Engelhart (KuK, 39-43) before, being unable to restrain himself any longer, intervening and causing Engelhart to walk out in anger at having his authority challenged (KuK, 43-44). Like Irene he has recognized the advantages of a normal existence, as opposed to an artist's, as he tells Bohl:

Es klingt ganz sonderbar - Heute habe ich meine Disziplin erkannt! Dieses kleine unscheinbare Geschäft zu führen, ist eine grosse Kunst. Der ganze Mensch muss dazu her, sonst taugt es nicht. Bohl - wie bei der Malerei...Dieses Geschäft will ich führen, solang ich kann, alles andere ist nichts für mich. Das habe ich heute gesehen, und $\mathrm{d} s$ [sic] weiss ich jetzt! (küsst Luise auf die Stirn.)

$(\mathrm{KuK}, 45)$

Fortunately, his wife seems very forgiving, allowing Lutmer to take up his position again in the firm and their marriage as if nothing has happened, presumably to live happily ever after.

The later play Der verschwundene Mond takes up issues already raised in the examination of "Kaufmann und Künstler" and Die Herberge. While the final version was published as late as 1985 , Hochwälder had written an "untaugliche Fassung" (IV, 43) as early as 1951, entitled "Der gestohlene 
Mond. Spiel in zwei Akten (zwölf Szenen)"78. The importance of this play to the author was emphasized by Hochwälder to Wilhelm Bortenschlager, describing it both as his "kostbarstes Stück" and a "Herzensangelegenheit"79.

The poetic nature of Der verschwundene Mond has pleasantly surprised at least one critic ${ }^{80}$, yet it is not the author's first departure from his more familiar "well-made" dramas, as Donnerstag and 1003. Stück in drei Akten show, and an earlier, unpublished, verse drama exists ${ }^{81}$. Furthermore, it was also conceived in the early 1950s, during the same period as Die Herberge was written, which Hochwälder also considered to be a lyrical work ${ }^{82}$. In addition to this, the action of both Die Herberge and Der verschwundene Mond takes place during the course of just one night ${ }^{83}$, "zwischen Abenddämmerung und Morgengrauen" (IV, 44), giving the events a mystical, unreal quality.

While the lyrical concept of the earlier work, "Der gestohlene Mond", is evident, the poetic quality was considerably refined before the final version, Der verschwundene Mond, was published. This may partly account for the author's dissatisfaction with the earlier draft. The 1951 typescript also lacks the economy of the published play with its central character, Gustave, a less sympathetic and articulate figure. This necessitates the use of secondary characters, such as the accountant, a fellow tramp, Pépe ${ }^{84}$, and a thief, to convey important information, which is provided in Der verschwundene Mond by the protagonist himself, often through his poetry. Nevertheless, the central thematic concern remained consistent during the three and a half decades that Hochwälder worked on the play: the belief that money and success alone can bring happiness and personal fulfilment is a dangerous folly.

78 Fritz Hochwälder, "Der gestohlene Mond. Spiel in zwei Akten (zwölf Szenen)", ts., 1951,
Hochwälder Nachlaß, Wiener Stadt- und Landesbibliothek, Wien.
79 Bortenschlager, Der Dramatiker Fritz Hochwälder, 91.
80 Lutz Hagestedt, "Der verschwundene Mond", Süddeutsche Zeitung [München], 2. Nov.
1985 .

81 Fritz Hochwälder, "Eulenspiegels Erdreich", ts. 1937/38, Hochwälder Nachlaß, Wiener Stadt- und Landesbibliothek, Wien.

82 This is made clear in notes on Die Herberge written by the dramatist:

Das Stïck ist - mit Ausnahme einiger Verhörspartien im 2. und 3. Akt - bloss scheinbar in Prosa geschrieben.

Der Sprachrhythmus des Gedichtes - denn um ein solches handelt es sich - darf nicht durch einzelne kleine und kleinste Striche unterbrochen werden.

Die Legende soll durch ihre Einfachheit wirken, die Stille, das Schweigen, die Pausen sind ebensowichtig wie der Text.

- Fritz Hochwälder, typed "Bemerkungen" to the 1957 Burgtheater production of Die Herberge, Hochwälder Nachlaß, Wiener Stadt- und Landesbibliothek, Wien.

83 As does the action of both Donadieu and 1003 .

84 Bortenschlager, in his brief examination of "Der gestohlene Mond", mistakenly attributes Pépé's view of the life of a tramp to Gustave [W.B. Der Dramatiker Fritz Hochwälder, 92]. 
Both plays are introduced by the W. B. Yeats poem, "The Witch", which both warns of the dangers of materialism and striving for wealth, as well as foreshadowing the events which will follow in the play:

Toil and grow rich,

What's that but to lie

With a foul witch

And after, drained dry,

To be brought

To the chamber where

Lies one sought

With despair.

$\left(\right.$ DGM, ii) ${ }^{85}$

In "Der gestohlene Mond" bourgeois striving and limitations are immediately shown by the opening conversation between the accountant and newly promoted postmaster. The accountant, while happy about his friend's advancement, questions whether he can be truly contented with his lot, for, as he admits at the end of the scene, he is far from contented with his own life (DGM, 9). This dissatisfaction with his own life is reflected in the unlikely admiration he has for Gustave. He tells the sceptical postmaster ${ }^{86}$ : "Du solltest ihn einmal sehen, wenn der Geist über ihn kommt, da glaubst du, er wär des lieben Gottes Duzbruder. In diesem Menschen lebt etwas, das wir alle nicht haben..." (DGM, 4). He provides the necessary expositional detail, recounting how the tramp had shown he could take the moon from the sky (DGM, 5).

The postmaster, however, is happy with his promotion and can confidently say to his friend: "[...] ich habe das Ziel meines Lebens erreicht!" (DGM, 1). Confronted with Gustave he can only see "Ein Clochard wie alle andern. Zerlumpt, verkommen, in Alkohol aufgelöst" (DGM, 4). Nevertheless, he too finds his own existence challenged by the vagabond, for when he asks what future such a man can have, he finds the question uncomfortably redirected at himself (DGM, 6), raising the issue of what can lie ahead for a man who has already achieved his life's ambition.

Aside from the accountant and the postmaster, the main representative of the middle-class virtue of honest hard work as the means of success, is, as in Der verschwundene Mond, André Pivert. In this earlier version the relationship between the two writers is more antagonistic, if only in the protagonist's $\operatorname{mind}^{87}$ : the successful, arrogant Pivert is scornful of Gustave, accuses him of

85 The question mark which is at the end of the original poem [W. B. Yeats, The Collected Poems of W. B. Yeats, London: Macmillan, 1950,135] is omitted in both the typescript and the published play. Der verschwundene Mond also has a confusing typing error which renders the penultimate line of the poem as "Lies on sought" [my italics] (IV, 45).

It is not hard to imagine that any audience watching "Der gestohlene Mond" would be equally sceptical given Gustave's appearance and behaviour - he is certainly not the poet of Der verschwundene Mond.

87 That this scene is imagined by Gustave is suggested in the second act when Pivert has no recollection of the encounter (DGM, 65), although at first he does display a similar 
jealousy, and is even, it would seem, a rival for the affections of Blanche (DGM, 14-15). The futility of Pivert's bourgeois striving only becomes clear to him, as in Der verschwundene Mond, when he discovers that Gustave has indeed taken the moon from the heavens. Recognising Gustave's extraordinary ability, he realises that his life has been meaningless:

Seit zwanzig Jahren mühe ich mich schweisstriefend Nacht für Nacht -setz Tintenwort an Tintenwort -- wie Ameisen laufen sie übers Papier -Millionen und Millionen... aber ich liebe sie nicht [...] Wie oft hab ich in bitterer Verzweiflung die Hand ausgestreckt - nach Gnade [...] alles was ich erreicht habe: Ruhm und Geld. - Was soll ich mit wertlosem Besitz? [...] Der Traum, der Mond, war nie in meiner Hand...

(DGM, 68-69)

The figure of Gustave in this earlier play is not the verse-spouting poet of Der verschwundene Mond, but rather an alcoholic, unhappy figure, with little to say in the opening scenes. It is left to the accountant to inform the audience of the tramp's ability to hold others in awe with his rhetoric (DGM, 5), and fellow vagabond, Pépé, is left to describe his lifestyle, while Gustave silently broods:

Was willst du? Gehörst du nicht zu uns? Hast du nicht auf alle Unannehmlichkeiten des Lebens verzichtet? Bist du den Schrecknissen des Alltags, als da sind: geregelte Arbeit, Einkommenssteuer, Weib und Kind, bürgerliche Behausung, verschärft durch Doppelschlafzimmer, Mahagoni fourniert oder Eiche massiv - nicht glücklich entgangen? Worüber grübelst du, was willst du noch?

(DGM, 10-11)

Pépé also provides a diagnosis of the problem which prevents the taciturn protagonist from fully embracing the life of a clochard: "Deine Verkommenheit bleibt im Aeusserlichen stecken, und alle Aeusserlichkeiten sind ungesund, im höchsten Grade ungesund ..." (DGM, 11).

It is just such an "exterior appearance" that leads Gustave to make the fatal error of taking the moon from the sky. The beautiful vision of Blanche throws Gustave into confusion and embarrassment over his sorry state, despite his protestations that it is already too late for him (DGM, 7). Both her name and her white attire, suggest a purity, which like the encounter itself is not real. It later transpires that the meeting, like that with Pivert, has been imagined by the protagonist (DGM, 54) for the real Blanche insists to her madame later that she had not visited Gustave. He remains melancholic after this first "encounter", but what prompts him into action and the theft of the moon is the (imagined) meeting with Pivert, in which the successful writer says that Blanche is waiting for him (DGM, 15). Gustave's motivation here is base jealousy and a desire not to be outdone by his rival.

Having committed the crime, the immediate course of events is similar to arrogance. 
those of Der verschwundene Mond. Gustave sells the moon to make himself presentable to Blanche, only to find he has deceived himself. However, unlike the Gustave of Der verschwundene Mond, the protagonist here shows a certain avarice: he haggles over the price of his new clothes (DGM, 49) and is far less generous with his money when it comes to visiting Blanche, so that the madame must encourage Blanche to do her best to relieve him of it (DGM, 55).

The scene with the thief, which begins Act II, is also markedly different from the final version of the play. Again, significant information is conveyed by a secondary character, the protagonist remaining largely inarticulate. Gustave, having committed his crime, is literally unable to act, simply staring into the Seine. It is the thief who reveals the magnitude of his crime:

[...] Den Mond zu stehlen, den Mond! -. Gibt es für unsereinen nicht Auswahl genug? -- Alles was die Menschen in ihrer Denkfaulheit als Eigentum bezeichnen, steht einem rechtgeschaffenen [sic] Dieb zur Verfügung. Denn was ist Eigentum, wenn man es genau definieren will? Irdischer Tand, den quasi Besitzern nur für kurze Zeit verliehn! Infolgedessen spielt es keine Rolle, wenn der Plunder vorübergehend Hand wechselt! Auf diese unzweifelbare Wahrheit gründet unser Gewerbe, das nicht mehr und nicht weniger schmutzig ist als jedes andere. [...] Aberd en [sic] Mond zu stehlen, den Mond! -- Weisst du nicht, dass es Dinge gibt, die man nicht antasten darf, die für alle da sind und über allen bleiben müssen, über Reiche und Arme, Faule und Fleissige, Dumme und Kluge, über Ehrliche und über Diebe? --- So ein Ding ist der Mond - seit Ewigkeit und so fort! -- Wenn der Mond nicht mehr am Himmel wär, da gäb es ja überhaupt nichts mehr Höheres in der Welt, dann müsste man ja verzweifeln!

(DGM, 61-62)

Property may indeed be theft, to paraphrase Proudhon, but the outrage Gustave has committed is selfishly to take for his own pleasure something that no one owns, yet can provide inspiration for all.

Finally in this earlier version, as in Der verschwundene Mond, after trying and failing to buy back the moon, Gustave gives the money to the flower girl before dying. He now recognises the folly of believing money is the way to happiness.

Between 1951 and the final publication of Der verschwundene Mond, significant alterations in the play took place. This applies particularly to the protagonist, whose characterization in "Der gestohlene Mond" was weak and unconvincing. As has been observed, since he remains largely silent, secondary characters are repeatedly required to provide information about him and his actions. A prospective audience would learn from the Buchhalter about Gustave's great ability, but never see it, and its significance must later be conveyed by Pivert, who makes it clear towards the end of the play that Gustave's ability to take the moon from the sky represents a poetic gift he 
cannot hope to attain (DGM, 68-69). However, his judgement that Gustave has done this from envy and is "keines vernünftigen Gedankens fähig in [seinem] Trinkerhirn" (DGM, 68) is scarcely contradicted by Gustave's behaviour. It is his jealousy of Pivert that motivates him into action, and once wealthy he seems loath to part with his money. Even after he discovers the truth about Blanche, his suicidal mood might just as well be a result of selfpity as remorse, for it is the thief who must articulate the gravity of his crime. Indeed, the protagonist does little during the play to earn the sympathy of an audience, and might well earn its antipathy.

Der verschwundene Mond owes its completion, according to Hochwälder, to the rediscovery of the work of Jakob Haringer, whom Gustave now fully represents (IV, 43), and whose poems are quoted throughout the play. It is this poetry which gives the protagonist the convincing voice absent in the earlier version, generating the pathos in the play and sympathy for its hero.

That the play is far more lyrical than its predecessor is apparent from the opening lines, when the flower-girl sings her song, this time a German rendition of Yeats" "The Witch"88:
Plag dich,
werd reich -
Was ist's,
als bei einer faulen Hexe liegen,
bis man dich
dürr und bloß
in die finstre Kammer schmeißt.
Dort liegt sie, die du begehrst,
die du in Verzweiflung suchst,
liegt in deiner letzten Kammer.

The alteration made to the emphasis of the original is striking and can be compared to a more accurate translation provided by Bortenschlager in his examination of "Der gestohlene Mond":

$\mathrm{Zu}$ arbeiten und reich zu werden

was ist das andres

als bei einem faulen Weib

zu liegen und dann ausgetrocknet

in das Zimmer gebracht zu werden

wo die liegt, die man voll Hoffnung gesucht hat ${ }^{89}$.

While Hochwälder's words "plag dich" and "Hexe" are preferable to Borten-

88 The Blumenmädchen also appears in "Der gestohlene Mond" and does sing, but the song is not identified as the poem, nor does she exchange words with Gustave. However her connection with death is still apparent when he goes to sleep with his head resting on her lap, at the end of the play.

${ }^{89}$ Bortenschlager, Der Dramatiker Fritz Hochwälder, 94. 
schlager's "zu arbeiten" and "Weib", his use of "schmeißen", "finster", "in deiner letzten Kammer" and the use of the second person singular pronoun significantly alter the stress of the poem. The warning of death after a futile search for something that will not bring true happiness has been personalised and directed at Gustave. Since his actions will bear out its message, this can be seen as yet another example of dropping hints of what is to come. The warning is repeated just after he has taken the moon (IV, 51) and further emphasised when the flower-girl sells Rachman a poppy, just before he dies (IV, 61 $)^{90}$. But Gustave is oblivious to the warnings, even when his attention is drawn to her: "Mädchen, Mohn im Korb? - Nichts gehört, nichts gesehen" (IV, 46). He is left to regret this at the end, when it is too late:

GUSTAVE: Mädchen - warum bist du mir nicht früher begegnet?

MÄDCHEN: Du wolltest mich ja nicht sehen [...]

GUSTAVE: Mein Gott, was war ich für ein Narr!

Nevertheless, the Gustave of this play seems much more aware of what he is doing and the possible conseqences of his actions. He spells out the symbolic nature of the moon to fellow clochard Clodo:

GUSTAVE: [...] Der Mond, das ist die lautere, ewige Dichtung, die unangetastet bleiben muß.

CLODO: Aber der Mond, heißt es, ist doch 394.000 Kilometer weit entfernt $[\ldots]$

GUSTAVE: Das gehört zu den wissenschaftlichen Ammenmärchen. Blick hinauf, schau ihn an, betracht ihn: Der Mond ist in Wahrheit eine Münze aus reinem, unverfälschtem Gold.

(IV, 47-48)

But while recognizing the importance of the moon, he is also fully aware of his position in life and describes it to Clodo with a mixture of resignation and sadness:

GUSTAVE: Ich neide niemandem etwas. Wer bin ich, was bin ich? - "Ich bin ein Fremdling, einst war ich ein Dichter.Ich bin der letzte Morgengast der müden Hur. Ich bin die Wand, die alles hört und nichts sagt."

CLODO: Ja, eben. Leute, die was davon verstehn, behaupten, du seist begabter gewesen als André Pivert...

GUSTAVE: Schon möglich. Aber..."Ich kann nichts als meine armen Verse schreiben. Ich habe kein Geschick zu Dramen und Roman. Das Leben hat ja Platz auch in acht Zeilen - Und Bände da zu schmieren dünkt mich Wahn."

(IV, 47)

90 The flower-girl serves a similar function to Kapora in Donnerstag; both warn of impending death. 
He does not envy the successful writer, Pivert, echoing sentiments expressed in Die Herberge with his "Jedem das Seine" (IV, 49) and sees him as a "Schwerverdiener" (IV, 49), who has failed to realize that to do nothing is "das vernünftigste" (IV, 48).

Yet the poem he recites after meeting Pivert, with its images of loneliness and lack of luck, suggests that he is far from content. It is just at this moment that Blanche appears to tempt him (IV, 49). Unlike in "Der gestohlene Mond", it is Blanche who gives Gustave the idea to take the moon: "Nimm ihn für mich, und komm, wenn du präsentabel bist, ich erwarte dich" (IV, 50). However, as in the earlier version, it is suggested that she is a vision, for, after having told him to come to her, "sie verschwindet" (IV, 50). Certainly, she shows no recollection at their later meeting (IV, 68). She appears as part of Gustave's fantasy just when he is feeling lonely.

After this, Gustave's efforts to sell the moon follow a similar path to "Der gestohlene Mond". Hochwälder has, however, embellished some of the figures Gustave meets from real life, based on newspaper articles. The "Chef" is based on the London based criminal, Peter Rachman, who came to prominence on the fringes of the so-called "Profumo-Affair" in the early 1960s. Much of the biographical detail and dubious business practices, which the Rachman of the play recounts (IV, 59-60), as well as the names of his henchmen, Attilio and Salvatore Messina, correspond to information on the real Rachman given in an article left in the Nachla $\beta^{91}$. Likewise, the seemingly fantastic scheme of Mr. Smith to sell real-estate on the moon is based on a newspaper report ${ }^{92}$. These characters serve to add further criticism of greed in society, which not only leads to the exploitation of others, but also does not really provide any satisfaction or happiness. They have chosen to "lie with the foul witch", and to ignore their consciences. The key figure in this is Rachman. He tells how, in his determination not to lead the same miserable existence as his father, he embarked on a career of crime and exploitation of his fellow man. In doing so he quite consciously sacrifices the moral scruples of his father: "Ideen waren mir stets gleichgültig, Moral kannte ich nicht" (IV, 59). He embarks on a highly successful criminal career, mercilessly exploiting "diese hoffnungslose Menschheit, die alles mit sich geschehen läßt, nur nichts Vernünftiges" (IV, 54). But all his dubious achievements, which have earned him the title of "König von Pigalle", have ultimately not resulted in a more fulfilling life than his father's. With this realisation he has lost his famous mocking laugh, and with it all interest in business (IV, 60), much to the consternation of his underlings. It is in this melancholic state that he observes the nasty end that befalls the crayfish, which is also a "Räuber, bösartiger Räuber" (IV, 57).

Those around the "Chef" are also motivated purely by self-interest. Attilio and Salvatore are concerned to get Rachman laughing again because they know

91 Anonym, "Rachman. Herrscher des Slums", Der Spiegel [Hamburg], Nr. 32, 7. Aug. 1963, 42-43. [Found in Hochwälder Nachlaß, Wiener Stadt- und Landesbibliothek, Wien].

92 "Mister Coles verkauft den Mond", date and publication unknown, Hochwälder Nachlaß, Wiener Stadt- und Landesbibliothek, Wien. 
their own livelihood depends upon it (IV, 53-56). Lucette puts up with his strange mood because of what she hopes to get out of him: "eine Villa in Neuilly" (IV, 56). As soon as Rachman is dead, these "Hyänen und Schakale" $(\mathrm{IV}, 60)$ pounce on his money. No one mourns his passing. As the scene ends the melody of the flower-girl plays in the background, once again symbolising mortality and the futility of material striving (IV, 61-62).

By having the eventual purchaser of the moon an American, Hochwälder is aiming a barb at that bastion of capitalism and materialism. In "Der gestohlene Mond" he is a drunken salesman, who, echoing the sales pitch aimed at Pomfrit in Donnerstag, sells "all the things that make life more comfortable" (DGM, 44). Having bought the moon he gloats "Now we have all things from poor old Europe - even the moon!" (DGM, 45). The later version is slightly more subtle, and the rather peculiar English is mercifully dropped. Here, Mr. Smith appears to have a genuine interest in astronomy: "Kürzlich hat man mich an meinem Wohnort Long Island zum Verwaltungsrat-Vorsitzenden des New Yorker Planetariums gewählt" (IV, 63). However, no sooner has he purchased the moon, than he is planning how to make a profit from it: "Ich sehe nicht ein, warum ich den Mond nicht bereits als Abwesenden verkaufen soll. Ein Gleiches haben wir in unserer Vergangenheit mit Land in Texas und Klondyke getan" (IV, 65).

Having acquired the money, and having made himself presentable (IV, 66), Gustave is ready for Blanche. In another redeeming feature at variance with "Der gestohlene Mond", he readily follows the example of Balzac and gives all his money to Biffine, as a demonstration of his love (IV, 67). Clearly wealth has never been the object for the protagonist, but rather he has devoted himself to a misguided ideal of love, which he believed could be bought. This becomes clear when he finally sees Blanche, who does not welcome him with open arms, and who presents a ghastly picture: "Genick und Schultern sind übersät mit Warzen und Schwären, so gleicht sie einer abscheulichen Hure, wie sie der Maler Félicien Rops dargestellt hat" (IV, 68).

In the surreal last scene of the first act Gustave finds himself accused by all the previous characters who have pursued money, including the dead Rachman. It is not the fact that he has stolen the moon that offends these capitalists but his motivation for doing so: "Für diese Person hat er den Mond gestohlen!" (IV, 68).

The short second act follows Gustave's vain attempts, despite Pivert's help, to buy back the moon. Pivert is another character who must recognize that success and material reward do not guarantee happiness. He is critical of Gustave for not having done more with his gifts, having been recognized by Malraux and Döblin ${ }^{93}$, yet despite the money and recognition he himself has attained, he still wants more:

Wer sagt, daß ich zufrieden bin? - Gewiß, meine Bücher sind beliebt bei

93 This clearly is an allusion to Haringer, who was criticised for not making more of his gifts and the prominent support he received. 
der Leserschaft, jeder neue Roman wird veschlungen, keine Erstauflage unter 100.000. Ich verdien einen Haufen Geld damit [...] Aber die allmächtige Kritik erkennt mich nicht an, hartnäckig disqualifiziert man mich als öden Erfolgsschreiber. Andauernd hält man mir Thomas Mann, Robert Musil und Canetti vor. Warum eigentlich, weshalb? (IV, 48-49)

The answer to this question becomes apparent at the second meeting. Pivert is shown to work relentlessly through the night in an austere existence indicated by his attire, which resembles that of a Dominican monk (IV, 70). Yet, it is now clear that he will never achieve his goal, and his efforts are presented as comical, for having finished one novel, he immediately starts on the next:

GUSTAVE: Gönnst du dir keine Ruhepause?

PIVERT: Nein.

GUSTAVE: Und die Erfolgssträhne reißt nicht ab?

PIVERT: Nein. Nicht bei mir.

GUSTAVE: Hast du schon einen Titel für den Roman?

PIVERT: Natürlich. Ein guter Titel ist wichtig für den Erfolg.

GUSTAVE: Und wie lautet er?

PIVERT: Da keine Trommeln und keine Trompeten im Roman vorkommen, nenne ich ihn "WEDER TROMMELN NOCH TROMPETEN".

It is only when he learns that Gustave has the poetic ability to take the moon from the sky, that he is forced to recognise how futile his own striving for recognition has been: "Erst sehe ich, was ich zeitlebens nicht wahrhaben wollte - dieses nämlich -, daß der Gescheiterte der Edlere ist" (IV, 71). He now realises that, no matter how hard he works, he will, literally, never be able to reach the same heights as Gustave.

But despite Pivert's help, Gustave cannot get the moon back. In the final scene his poetry indicates that he is ready to die:

Blumen werden blühen

Bald wieder blau und rot,

Und die Abende hold verglühen,

Ich aber bin lang schon tot.

This is followed, just before he dies, with the last stanzas of Haringer's free rendering of François Villon's "le testament" (IV, 74-75).

Now, finally, he notices the flower-girl, and he recognises what a fool he has been (IV, 73). They embrace, but it is too late for them: "Ohne Mond keine Dichtung - und ohne Dichtung keine Liebe, kein Leben" (IV, 74) ${ }^{94}$. He sees that the pursuit of money is foolish: "Geld ist das armseligste Ding - man kann nichts von wirklichem Wert dafür kaufen - gar nichts" (IV, 74). Never-

94 Despite this, as has been seen, he still managed to recite his own poetry in this final scene! 
theless, he gives the money he got from Pivert to the flower-girl, so at least she will not have to sell flowers any more. After she has left he recites his final verse, lies down and dies. When Clodo discovers him, the moon is back in the sky (IV, 75), the price for its return seems to have been the death of the poet. He has not been able to live with what he has done.

It has already been observed that the girl seems a messenger of death during the play, but in this final scene she represents more than this. Here she also symbolises the happiness that was under Gustave's nose, if only he had chosen to look. Instead he sought wealth to pursue Blanche. So Lutz Hagestedt is partly correct when he claims "Sie verkörpert das Stille, einfache Glück, unerreichbar für Gustave, solange er Geld in den Händen hält" ${ }^{95}$. However, it was not the money itself which prevented Gustave from gaining happiness, rather his own failure to see what was truly valuable - he failed to see the girl, despite Clodo drawing attention to her, before taking the moon (IV, 46).

Gustave's failure is not to use his great gift wisely. His poetic ability is such that the likes of Pivert can only envy him, but he allows his fantasy (the vision of Blanche) to blind him to reality. In pursuing this misguided dream he does what he knows to be wrong. In the end, he recognises the folly of this and that, regardless of wealth, death comes to all:

Und doch, ob arm, ob Pfaff, ob reich,

Ob edel, groß und klein,

Dem Tod ist Putz und Flitter gleich,

Und Schmuck und Ehre eins.

Bortenschlager sums up the message of "Der gestohlene Mond", which applies equally to Der verschwundene Mond:

Das Streben nach materiellen Gütern, nach Reichtum, Besitz, die Karrieresucht der modernen Gesellschaft verschütten das Echte und Wahre, die Phantasie und nehmen den Menschen das Glück. Symbol für dieses Echte aber ist der Mond, der romantische ohne Fahne der Astronauten. ${ }^{96}$

Jakob Haringer might also be quoted to illustrate this central theme:

Erwartung ist alles und immer das Schönste. Die in der Sehnsucht leben, wachsen zu Riesen. Man besitzt nie einen Menschen mehr, als wenn man ihn nie besessen. Das Erlebnis ist der Grabstein der Phantasie, schon deshalb flieht der Träumer oft die Erfüllung seiner Sehnsucht ${ }^{97}$.

This theme of pursuing a fool's gold is also central to Donnerstag, in which the conscience itself is seen, by some of the characters at least, as a trouble95 Hagestedt, "Der verschwundene Mond", Süddeutsche Zeitung [München], 2. Nov. 1985.

96 Bortenschlager, Der Dramatiker Fritz Hochwälder, 94.

97 Jakob Haringer, Das Schnarchen Gottes und andere Gedichte, hrsg. Jürgen Serke (München, Wien: Carl Hanser, 1979), 122. 
some impediment in the pursuit of pure materialistic, and hedonistic pleasure. The play, written for and first performed at the 1959 Salzburger Festspiele, is arguably Hochwälder's most ambitious work, both stylistically and thematically. It marks a radical departure from the conservative construction of the plays that established his reputation ${ }^{98}$, although the dramatist was keen to emphasize that its roots are firmly in the Austrian theatrical tradition:

Im Formalen hatte ich dem modernen Mysterium die Spielmöglichkeiten des österreichischen Zaubertheaters zugeordnet, die Volksfiguren sprechen Vorstadtdialekt, der Detektiv verfügt über eine magische Virginier-Zigarre, deren Rauch ihn augenblicklich zum Verschwinden bringt - kein Stilexperiment, wie ich meine, vielmehr Fortsetzung einer autochthonen Entwicklung. Freilich hatte ich dabei außer acht gelassen, daß ein derart naives Spektakel unserer theaterfremden Bildungswelt weitgehend unverständlich bleiben muß, zur Tradition gehören eben zwei: der Dichter und das Publikum ${ }^{99}$.

The play also owes much to both the Jedermann and Faustian traditions. Pomfrit is a successful but dissatisfied striver driven by "der protestantischen Ethik" (III, 127), who is tempted by the modern "Teufelspakt" 100 offered by the shabby Mephistoesque figure of Wondrak: happiness in return for the soul.

98 The uncompleted and undated typescript, "Schicksalskomoedie in zwei Akten" (Hochwälder Nachlaß, Wiener Stadt- und Landesbibliothek, Wien) was, according to the author, written around this period (Brief an Elwood Chandlee, Okt. 6, 1978, in: Chandlee, 166) and has thematic and stylistic elements in common with Donnerstag. The otherwise comprehensive overviews provided by Bortenschlager (Der Dramatiker Fritz Hochwälder) and Böhm (Fritz Hochwälder. Ausstellung der Wiener Stadt- und Landesbibliothek [...]) make no mention of the fragment, of which only the first act and an outline of the second exist, perhaps because in Hochwälder's opinion: "Den Titel [...] kann und muß man streichen" (Chandlee, 166).

The plot concerns the desires of the Carstiaun brothers, to be played by the same actor wearing different masks, to change their one-dimensional personalities: Alexi is irritable and hottempered ("zornig-rote Maske"); Baltan constantly cheerful ("heiter-rosige Maske"); Crest is apathetic and indifferent to life ("gleichmütig-gelbliche Maske"); and Dumeng is melancholy and suicidal ("traurig-graue Maske"). An advertisement from a mysterious family Destino which promises to transform individuals seerns the answer to their desires, and when the family appears the brothers are soon persuaded to be changed at the appointed hour. It is with this that the typescript concludes.

The air of mystery and magic surrounding the Destino clan is heightened by the failure of the brothers' servant, Stutz, to find anything written on the supposed advertisement: "Und auf so etwas, auf ein Nichts von einem Nichts, setzt der Mensch seine Hoffnung!" [7]. When the family does indeed appear they are not interested in the factotum, who serves a very similar function in the play to that of Birnstrudl in Donnerstag. The mystery is then further heightened when they themselves suggest they are not real: "[...] es darf nicht ruchbar werden, dass es uns nicht gibt!" [32].

A partial outline of Act II suggests that having sampled alternative personalities the brothers learn their lesson and, returning to their old selves, make the most of what they have.

99 Hochwälder, Im Wechsel der Zeit, 96-97.

100 Hochwälder, Im Wechsel der Zeit, 96. 
In the manner of the medieval Everyman play, Pomfrit, who is "für unsere Zeit signifikant" (III, 123, 127, 134), is surrounded by both false (Persenbeug, Kormoran, Amalie) and true friends (Kapora, Estrella, Thomas), who battle for his soul as his Day of Judgement (Thursday) approaches ${ }^{101}$.

However, while Hochwälder blamed the play's relative failure ${ }^{102}$ on the audience's ignorance of theatrical tradition, and taking into account the problems caused by the late replacement of the leading actor just two weeks before the première ${ }^{103}$, certain flaws in the play are unmistakeable. In places the play is simply too verbose, with both Pomfrit and Wondrak inflicting lengthy monologues on the audience ${ }^{104}$. Like Der verschwundene Mond, the play has an air of the magical and mystical, but, while in Der verschwundene Mond this is created through relatively simple means, Donnerstag relies on many special effects and runs the risk of distracting and confusing an audience. This also places a heavy reliance on a good technical production. It is also too long, and even a reviewer favourable to both the Salzburg and later Burgtheater productions, noted that the reduction of the playing time from three and a half hours to two and a half, greatly aided the presentation of the play ${ }^{105}$.

Nevertheless, the play is important in the development of the dramatist, and is a bold attempt to explore further concerns central to Hochwälder's work: the relationship of individuals to responsibility both for themselves and others; and the nature of modern society and the threat the dramatist perceived to individual freedom. In light of this, it is disappointing to see the play often given cursory attention in the secondary literature ${ }^{106}$.

101 For a more detailed examination of the influence of the Jedermann tradition on the play see: Herbert Knust, "Moderne Variationen des Jedermann-Spiels", Helen Adolf Festschrift, Hrsg. Sheema Z. Buehne, James L. Hodge, Lucille B. Pinto (New York: Ungar, 1969), 309. 341 .

102

Gotthard Böhm notes that the play received a much better reception after being revised (and considerably shortened) for the subsequent Burgtheater production. Nevertheless, as Hochwälder's defensive tone would suggest, the play was hardly a resounding success [G. B., "Der geborene Dramatiker: Fritz Hochwälder", 541-542].

103 Fritz Hochwälder, speech preparations under the title "Über mein Theater", undated, Hochwälder Nachlaß, Wiener Stadt- und Landesbibliothek, Wien.

104

George Wellwarth, rather unkindly, talks of "Hochwälder's reliance on the monologue as a substitute for plot" [G.W., "Fritz Hochwälder. The Drama within the Self", 219-220].

105 Piero Rismondo, "Donnerstag erlebte seine zweite Uraufführung”, Die Presse [Wien], 3. Dez. 1959.

106 This is especially so when it seems directly relevant to the subject matter under discussion, such as in Maria Holdman's, "The Concept of Order in the Drama of Fritz Hochwälder" and U. Henry Gerlach's, "Das Motiv des unterdrückten Gewissens in den Dramen Fritz Hochwälders".

Holdman's dissertation concerns itself with the inter-relationship between social and political order and the personal order and stability of the individual, which often comes into conflict as the individual is required to conform (cf. 20-22). Since a highly questionable solution to this problem is proffered by Maskeron in Donnerstag, it is unfortunate that Holdman chooses to ignore the play. 
The play takes up the same themes seen in Der verschwundene Mond, demonstrating that striving for success and recognition (Pivert) cannot bring fulfilment, nor can happiness and existential meaning be bought or traded. However, while at the end of Der verschwundene Mond Gustave comes to recognise this, it remains unclear whether Pomfrit will ultimately reach the same conclusion.

The protagonist introduces himself to the audience and recounts his considerable success with a large measure of pride and self-importance, even though it has not brought him happiness:

Ich war ein großer Architekt! Überhaupt, was war ich nicht alles: Freimaurer, Sozialist, Antialkoholiker, Vegetarier, Methodist, Reaktionär, Whiskysäufer, Europäer, Weltbürger, Nihilist, Existenzialist, zuletzt gar nichts, und sogar das hab ich noch unterboten - seit Mitternacht bin ich so gut wie tot, lassen Sie sich nicht täuschen, der Schein trügt, alles ist tot und dreht und bewegt sich, warum nicht auch ich, der Gepriesene, Preisgekrönte, Berühmte, Erfolgreiche? - Evoe! der große Architekt ist tot! Pomfrit a. D.

Ironically, Pomfrit, who has devoted himself to "die Totalität Mensch" (III, 125), has discovered his own life to be lacking in the essential elements of humanity: "[...] zum erstenmal in meinem Leben, fand [ich] mich in Ruhm und Reichtum bloß und nackend, ärmer als ein Bettler, an Seele krank, unglücklich und einsam! Einsam! - Ohne Glaube, ohne Liebe, ohne Hoffnung ${ }^{107}$, ohne Ideal, ohne Überzeugung ohne Bindung [...]" (III, 127-128). He has announced his own death in the papers and, confident of success, intends to find happiness by Thursday. Hitherto he had successfully avoided the emptiness in his life through hard work: "[...] die protestantische Ethik trieb mich an, bloß nicht zu Bewußtsein kommen, nur nicht nachdenken [...]" (III, 127). Since this no longer works he has correctly recognized where the problem lies: "[...] mein Verfolger war - niemand anders als mein eigenes

Gerlach dismisses the play too easily:

Im [Donnerstag] [...] spielen Gewissen und Gewissensunterdrückung nur eine indirekte Rolle, denn es geht dem Großingenieur Maskeron, d.h. dem Oberteufel, darum, die freie Wahl der Menschen zu unterbinden, d.h. solche Zustände herbeizuführen, die Gewissensentscheidungen, ja Entschlüsse jeglicher Att, unnötig und unmöglich machen. Während also die Figuren des Stückes nicht bewußt gegen ihr eigenes Gewissen handeln, will Maskeron das Gewissen allgemein unterdrücken, um damit den Menschen zum Nicht-Menschen, zum regulierbaren Automaten zu machen (68).

While Maskeron does wish to do away with the human conscience, he aims to do so by persuading Pomfrit to give up this troublesome attribute voluntarily, and so the deliberate suppression of conscience is central to the play.

In the choice of these three virtues Hochwälder may be paying tribute to Ödön von Horvàth's play Glaube, Liebe, Hoffnung. Ein kleiner Totentanz in fünf Bildern which contains the line "Ohne Glaube Liebe Hoffnung gibt es logischerweise kein Leben" [Ö. H., Gesammelte Werke, Frankfurt/M.: Suhrkamp, 1970, 353]. Both dramatists use modernised aspects of the Wiener Volksstück to convey their concern with the dehumanising nature of modern society, which robs the individual of any chance of genuine happiness. 
Ich!" (III, 130) ${ }^{108}$, yet he still refuses to confront himself: "Das Leiden kommt aus dem Ich, meide das Leiden vergiß dein Ich!" (III, 130).

This of course will not be easy, for Pomfrit is doing nothing short of trying to rectify the lack of the very human needs of Liebe, Glaube, Hoffnung by denying that which makes their absence felt: his humanity, his very self. This difficulty is symbolised by the recurrent motif of the Fettfleck on his jacket, which, despite numerous attempts, cannot be removed: "[...] der Fleck sitzt drin wie die Erbsünde im Menschen [...]" (III, 151).

No sooner has the protagonist announced his intention to forget his "Ich", than he finds himself imprisoned by his own ego, trapped by the echoes of "Ich! Ich! Ich!" (III, 131-132), and were this ego not so big he might even have committed suicide to escape it by throwing himself under the Orient Express. However, he stops himself at the last moment:

Was tu ich? - Wenn ich mich umbring, bin ich tot! - Tot! - Ein Wort, sinnlos, leer, unerlebt: kein Unglück mehr, kein Gram, kein Schmerz, keine Verzweiflung, kein Nichts, mein ein und alles zerschmettert, zermalmt, zerhackt wie aus dem Fleischwolf, und an den Schwellen klebt mein Hirn - undenkbar! Mein Hirn! - Ein Hirn, wie es in Jahrmillionen nicht entsteht, nie wieder [...] Ich häng an meinem Hirn, ich hab kein anderes, zum Teufel mit der Seele, wo ist die Hölle, die mich rettet?

Hochwälder himself said of his hero:

[Er] leidet an der Zeit-Krankheit totaler Glaubenslosigkeit, die zu Einsamkeit, massloser Ich-Bezogenheit und damit zum Irrsinn führt ... Pomfrit macht sich sogleich auf zur Jagd nach dem ersehnten "Du" doch wohin er sich auch wendet, überall schallt ihm aus Lautsprechern jenes fürchterliche "Ich!" entgegen, das ihn zur Einsamkeit verdammt ${ }^{109}$.

It is in this state of self-pity and confusion that Pomfrit has summoned up the devil to rid him of the burden of his soul (III, 133), and he is now a very vulnerable target for Wondrak and Maskeron. He is just the exemplary patient they are looking to cure: "[...] einen Menschen, der bei lebendigem Leib tot ist" (III, 123) ${ }^{110}$.

108 As will be examined later, the internal battle with oneself is a central concern in Hochwälder's work, and often takes on the form of a Jekyll and Hyde type conflict, cf. "Jehr", "Der Prozess" and Der Befehl. The notion of Selbstverfolgung also appears in Lazaretti oder Der Säbeltiger.

109

Fritz Hochwälder, "Donnerstag. Ein modernes Mysterienspiel", typed notes, undated, Hochwälder Nachlaß, Wiener Stadt- und Landesbibliothek, Wien, 1.

110 Daviau ["Der innere Konflikt [...]", 917] has drawn attention to the possible influence of Hofmannsthal's Der Tor und der Tod, a play which greatly influenced the young Hochwälder [cf. Fritz Hochwälder, "Marginalien zu Hugo von Hofmannsthal", Im Wechsel der Zeit, 51-53]. Certainly both characters find their lives dead and, having been unable to 
Maskeron shares Pomfrit's view that his problem lies with his "Ich" and offers nothing less than the "Erlösung des Menschen vom Menschen", the destruction of the root of the problem: the soul (III, 138). He offers Pomfrit what he thinks he is looking for, namely, happiness, through manufactured love, hope and faith, while ridding Pomfrit of any need to confront himself and his conscience.

Pomfrit's sudden readiness to accept Belial's offer belies the supposed intellect and culture of which he is so proud, for what Maskeron presents is nothing less than a glorified "Spießerdasein". The material possessions intended to provide what is missing in his life are: the ultimate bourgeois home with all the modern conveniences (III, 141-142; 154-155); the hope of space travel which will elevate man to God-like status (III, 142-143; 156-157) ${ }^{111}$; and last, but certainly not least, Pomfrit's dream sexual companion, Amalie, who seems the ideal woman to the protagonist, while for Wondrak her "Ordinärheit stinkt zur Hölle" (III, 148). As Eileen Murphy has observed ${ }^{112}$, it is ironic that Pomfrit, who prides himself on being a man of the twentieth century, should be most impressed by the appeal to his basest instinct that Amalie provides, and this, to some extent, reflects Hochwälder's own anti-intellectual stance $^{113}$. All too easily Pomfrit seems ready to accept the mediocrity of happiness offered by Belial: "Nicht Herz noch Seele - Norm ist unsere Rettung, Genesung Mittelmaß, das übers Ziel schießt: hinaus ins Weltall, in die Arme einer Göttin!" (III, 144).

So at the end of Monday, Pomfrit, oblivious to the danger he is placing himself in, is convinced that happiness can be procured, like any other material commodity, through Belial Inc. The battle for his soul only really begins on Tuesday.

As in the traditional Jedermann plays, it is the appearance of Death which alerts the protagonist to the true meaning of life and the error of his ways. In Donnerstag Josef Kapora appears in this role ${ }^{114}$, although, in the modern world he can no longer be clearly seen as a messenger for God, since the

strike up meaningful relationships with others, only come to value life when confronted by death.

111 In 1959 the space race between the United States and the USSR was just beginning and the play may reflect the general enthusiasm at the time for the prospects of space travel.

112

Murphy, 196-197.

113 In the above-mentioned outline entitled "Donnerstag. Ein modernes Mysterienspiel von Fritz Hochwälder", Hochwälder refers to his protagonist as "unsern intellektuellen Clown" (5), and both the stage instructions requiring the make-up for Pomfrit to suggest the face of a Pierrot (III, 124) and his name underscore this. Hochwälder's distrust of intellectuals receives its strongest dramatic expression in Lazaretti oder Der Säbeltiger, but is also clearly evident in Hochwälder's stinging attacks on modern experimental theatre, cf. Hochwälder, "Über mein Theater", German Life and Letters, 12, 1959, 102-114; Hochwälder, "Vom Versagen des Dramas in unserer Zeit", Im Wechsel der Zeit, 57-80 [see Chapter 7].

114 Cf. Fritz Hochwälder, "Donnerstag. Ein modernes Mysterienspiel von Fritz Hochwälder", typed outline with pencilled corrections, Hochwälder Nachlaß, Wiener Stadt- und Landesbibliothek, Wien, 5. 
existence of a higher being can no longer be taken for granted ${ }^{115}$. He warns Pomfrit of the dangers ahead:

[...]Wie wollen Sie sterben, Niklaus Manuel Pomfrit, wenn Sie Ihr "Ich" bei Leibe vernichten, auslöschen für ein totes Leben? Wissen Sie nicht, daß nur zu sterben vermag, wer wahrhaft lebt, und ist nicht allen Lebens Ziel ein guter Tod?

(III, 164)

He goes on to give the protagonist the message at the heart of the play:

Sie erstreben Hoffnung, Glaube, Liebe - Narr! Man begräbt Sie unter Allerweltsplunder, zu höchstem Preis! - Niemand, keine Gewalt, keine Macht kann Ihnen verleihn, was unerweckt in Ihrer Brust schläft: Glaube, Liebe, Hoffnung ... Befrein Sie sich, Mensch! - Sprengen Sie das Tor, öffnen Sie Ihr Herz dem Nächsten, Elenden, Beladenen, Ungläubigen, Lieblosen, sprechen Sie: "Nehmt! Nehmt!" - Und siehe da! Sie werden glauben, hoffen, lieben und sterben

(III, 164)

Initially Pomfrit is unimpressed with the message, with its metaphysical overtones:

Gaukler! Schwindler! Schwätzer! Heilsarmeeprädikant! Zwiefelpfaff! Taktätchenverkäufer [sic]! Was Sie verzapfen, imponiert mir nicht, Banalitäten, Phrasen, uralt, abgedroschen, seicht, flach und platt! Sie sind dennoch am Falschen, Herr Kapora, ich bin kein böhmischer Ackersmann, kein Kerzelweib mit Hühneraugen auf den Knien, ich bin ein gebildeter Europäer, hab im Breisgau studiert, wer mich belehren will, muß tiefer schürfen! - Tor sprengen, Herz und Seele öffnen, sprechen: "Nehmt! Nehmt!" - das riecht nach Weihrauch, tönt nach Kanzel! - Wem was anbieten? - Wenn nichts in mir ist und nichts außer mir, nichts als Ekel, weltweit verspritzte Kotze, Lemuren da, Lemuren dort, wie, wo, wem was geben? Stehn Sie Red und Antwort, Herr Kapora!

(III, 165)

Kapora must resort to inflicting a warning heart attack on Pomfrit, which is what brings him into contact with Estrella and Thomas (III, 165).

Both characters, like Pomfrit, are in need of human contact. Estrella is looking for someone to love, but both her state and the nature of modern mass society make it seem unlikely that she will be successful: "Wer sollt mich lieben, was ist an mir, Zotteln, nichts als Zotteln, [...] wer was Liebenswertes an mir fänd, müßt ein Narr sein, so einen gibt's nicht, und wenn es ihn gäbe, wo sollt ich ihn finden, mitten in der Nacht unter lauter wimmelnden Ameisen?"116 (III, 168). She has turned for hope to Frater Thomas, only to find he 115 Cf. Knust, 312-313.

116 The modern world is often likened to an ant colony in Hochwälder's work, reflecting his own concern with the dehumanizing effect on the individual of life in mass society [see 
has no solace to offer, since he has lost his faith through the inhumanity he has seen, in what is a clear reference to the Nazi holocaust (III, 166). He bears witness to what he has seen, not believing in man, God or love (III, 167).

However, when the three of them meet they are able to discover Liebe, Glaube, and Hoffnung within themselves, just as Kapora had earlier predicted. Faced by the frightening proof of his own mortality, Pomfrit's earlier vanity evaporates and he can now see himself for what he is: "ganz und gar nichts besonderes [...] ein eitler, törichter, schwankender, wankelmütiger, verwirrter, irrender, sehnsüchtig hoffender Mensch" (III, 171). Moved by Estrella's compassion for him, when all around ignored his plight (III, 169), Pomfrit falls in love with her, and this declaration restores Thomas' faith in humanity, despite what he has seen, for he has found a man in whom he can believe (III, 171). Significantly, the relationship between the three is one of giving and receiving, symbolised with religious imagery by the breaking of bread and drinking of wine. It is this most human interaction which now threatens to deny Belial success.

This, however, takes place on Tuesday, giving Maskeron and Wondrak Wednesday to undermine this fragile rebirth of faith, hope and love. Maskeron, confronted by the unpredictability of his human opponents ("Eine elende Münze, die fällt, wohin der Wind bläst - das ist der Mensch!" (III, 175) undertakes increasingly desperate measures to make sure Pomfrit chooses Belial. He decides to take care of Thomas personally, while leaving Estrella to Wondrak. In both cases, Belial is unable to stop the efforts of Pomfrit's friends, but can delay them long enough for Pomfrit to have to face his fateful decision on his own.

Thomas, with his new-found faith, is now convinced that society will see the error of its ways: "Der neue Glaube wächst: Erkenntnis, daß leere Leistung, Erfolg um des Erfolges willen, zielloser Besitz eine Herde von gesichtslosen Tröpfen auf glatter Straße mit hundertfünfzig Stundenkilometer ins eigene Verderben treibt!" (III, 181). He is determined to remain loyal to Pomfrit despite being called to appear before his religious superiors in a manner very reminiscent of Querini's directive to the Provincial in Das heilige Experiment. His attitude is, however, markedly different to that of Fernandez and he recognizes at once the inhumanity represented by large organizations:

Wer lädt mich vor, was hab ich mit großen Herren zu schaffen, bin nicht gesonnen, über Weltverbesserung zu schwatzen ... (Liest aus dem Brief:) "... dringliche Aussprache ... Traktandum, entscheidend für das Wohlergehen von rund hunderttausend Existenzen ..." (Blickt auf.) Rund! die Sprache der Statistik! Ein paar tausend mehr oder weniger - was verschlägts, es ist atmendes Material, eine Maschine, die programmiert wird und läuft, Ziffer und Zahl! [... $]^{117}$

(III, 181)

Chapter 7].

117 The parallel with the attitude of Querini in the earlier play is unmistakable: "Es geht um den

Bestand des Ordens - und Ihr sprecht von hundertfünfzigtausend Menschen!" $(1,124)$. 
Yet when his superior appears before him, in reality none other than a disguised Maskeron, the orders he receives, do, at least initially, cause him to hesitate in his loyalty despite his protestations (III, 183).

Wondrak is easily able to divert Estrella by playing on her sympathy. Disguised as a blind man he lures her to his "home", a Belial creation, where he drugs her to keep her from Pomfrit (III, 179-181).

Yet despite these measures Maskeron becomes increasingly nervous as the moment of Pomfrit's decision nears and he reveals his fear of the human spirit, angrily telling Wondrak:

Was ahnen Sie in Ihrer Niedrigkeit von des Menschen unermeßlicher Größe? Nichts ist ihm vorbestimmt, nichts kann seinen Willen auslöschen, er ist frei in seiner Wahl, frei bis zum letzten Atemzug! Wohin mit der Maschine, wenn Wankelmut und Schwäche, auf die wir bauten, sich plötzlich gegen uns kehren, wenn die geheimnisvoll geprägte Elendsmünze im Windhauch anders fällt?

(III, 185)

His fears certainly seem borne out by Estrella and Thomas, who at the very end race to find Pomfrit to be with him at the crucial moment (III, 190), although as the last scenes indicate, his decision is one that can be made by him alone (III, 197-198).

Pomfrit's behaviour, however, is less reassuring for the audience. He starts Wednesday full of new-found resolve after his meeting with Estrella and Thomas, but as soon as his servant has left, this becomes shaky (III, 178) and nears collapse when he goes to visit Amalie, supposedly to inform her of his determination to reject Belial. The sight of her again awakens his desire, and she plays on this by promising herself to him as soon as he has chosen Belial (III, 186-189).

After drinking with Wondrak, and in the process having learned more than he should have (III, 190-196), his indecision grows. He recognizes he was a fool to want to change himself, but has no idea how to extricate himself from his predicament. He hopes he may escape by not making a decision at all, but firstly Birnstrudl tells him he is obliged to (III, 194), and then Wondrak confirms this by producing the contract, not written in blood but on indestructible nylon, as befits the modern world (III, 196). He seems unable to defend himself against the temptation of the creations of Belial, who now openly reveal the true nature of what they have to offer:

PERSENBEUG: Hinauf! - Hinaus ins Wesenlose!

KORMORAN: Hereinspaziert! - Hinein ins Mittelmaß!

AMALIE: Die große Nacktrevue! Das Allerweltstheater! Hereinspaziert! Hereinspaziert!

(III, 197)

Pomfrit collapses, only to be encouraged by the vision of Estrella and Thomas (III, 197). He receives one last piece of advice from Kapora: "Verzweifle getrost, Mensch! Der Glaube kommt aus dem Nichts - ein Anruf auf dem 
Weg, ein ungeheures Licht - und ist nicht auch die Schöpfung aus dem Nichts erstanden?" (III, 197-198) but then must make the fateful decision on his own. Vacillating right up to the end and left praying to a God in which he does not believe, his final choice remains uncertain and is not revealed.

While the protagonist struggles under the burden of his impending decision, the character Birnstrudl is used to comment on and poke fun at Pomfrit's and human behaviour in general. The grumbling but loyal servant with his inordinate love of food ${ }^{118}$ would be at home in any traditional Volksstück. His presence constantly brings into question his master's pretensions and the notion of normality, for which Pomfrit craves, and which Belial claims able to provide. His constant battle with the symbolic Fettfleck serves to remind the audience just what is at stake [see above]. Self-interest always seems to be at the forefront of Birnstrudl's mind, yet he remains faithful to his difficult master, despite repeated threats to leave.

He first appears incensed at the actions Pomfrit has taken, which have had no regard for his position:

Wenn Sie sich umgebracht hätten wie ein normaler Mensch, aufgehängt oder erschossen, bitte sehr, dagegen wäre nichts einzuwenden, aber so was - das ist heller Wahnsinn, der indirekt auf mich zurückfällt, die Leute werden sagen: das muß ein feiner Diener sein, der so einen Herrn gehabt hat, mit Ihren Blödheiten schaden Sie meiner Karriere, haben Sie sich das nicht überlegt?

(III, 128-129)

Any normal misdemeanour, such as terrorism, gambling or sleeping with a minor, would gain Birnstrudl's understanding and even sympathy, but not this ridiculous death notice:

[...] Mit diesem Partezettel stelln Sie sich außerhalb jeder Realität, das ist das schlimmste Verbrechen und dementsprechend unverzeihlich, notabene, wie ich Sie kenn, bringen Sie sich nicht um, dazu haben Sie sich viel zu gern, Sie kokettieren mit dem Tod, wissen Sie, was Sie sind? (Mit unendlicher Verachtung:) Sie sind nicht normal!

(III, 129)

Clearly Birnstrudl's notion of what is normal is quite at odds with the quasiintellectual concerns of Pomfrit, and this is reinforced by his flippant dismissal of his master's theological musing:

POMFRIT freundlich: Nicht wahr, Birnstrudl - Sie glauben an nichts?

BIRNSTRUDL: Wer sagt, daß ich an nichts glaub?

POMFRIT: Woran glauben Sie?

BIRNSTRUDL: Ich glaub an ein saftiges Schweinsschnitzel, fein paniert mit blonden Semmelbröseln - sehr wichtig! -, dazu resch gebratene Kipfler, Gurkensalat und ein Viertel Gumpoldskirchner - ist das kein

118 A characteristic shared with Escambarlat in Donadieu. 
Glaubensbekenntnis?

POMFRIT: Selbst dieser Glaube fehlt mir ...

BIRNSTRUDL: Traurig, sehr traurig.

Birnstrudl also provides a commentary on the examination to which Maskeron subjects Pomfrit, instinctively realizing that the promise to turn Pomfrit into a happy, productive member of society sounds "lebensgefährlich" (III, 137), although he does not fully comprehend it. Infuriated by Pomfrit's behaviour and finding his answers to the questions put to him incomprehensible, a frustrated Birnstrudl can only reiterate "Sie sind nicht normal!" (III, 141).

His tune soon changes when he sees the material rewards being offered to Pomfrit, and his own "normal" human greed comes to the fore. He gives his own amusing answers to the questions hitherto put to Pomfrit and insists that he too be given the same opportunity, only to be told by Wondrak that he is already happy (III, 144). The disgruntled Birnstrudl is left to complain: "Möcht wissen, wieso und warum ich glïcklich sein soll ... Nur weil ich halbwegs normal bin und zufrieden mit dem, was ich hab? ... so eine niederträchtige Verleumdung ..." (III, 145).

But it is Birnstrudl's simple, straightforward and very human outlook that also means that he is as much incapable of understanding Pomfrit's Zeitleiden and feelings of isolation, as he is of really helping his master, and it is this that justifies Wondrak's claim that he is in on their side (III, 184).

Birnstrudl cannot understand Pomfrit when he starts to worry about his impending decision, having himself been taken in by the impressive material offerings of Belial. Being "normal" he cannot understand Pomfrit's enthusiasm for having made contact with fellow human beings (Estrella and Thomas): "Von der Sorte sandeln schon mehr als drei Milliarden herum, was haben Sie davon, möchten Sie mir das erklären!" (III, 176). He now actively encourages Pomfrit to choose Belial, while being confident that he will do so, unable to resist the charms of Amalie (III, 177).

Despite all his problems with his employer, Birnstrudl remains loyal right up until Pomfrit must make the decision, and makes one last futile attempt to get rid of the Fettfleck (III, 195). At their tearful parting of the ways he still hopes that Pomfrit will opt for Belial and normality, while at the same time recognising that whatever Pomfrit chooses they must part: "Wenn Sie sich für Belial entscheiden, wie ich zuversichtlich hoff, dann sind Sie morgen normal, und zwei Normale passen nicht zusammen; wählen Sie das G'lumpert, dann sind Sie parterr' und brauchen keinen Diener ..." (III, 194). Here Birnstrudl, perhaps inadvertently, hits at the very heart of what is really on offer from Belial, for if two normals do not belong together, the normality available from Maskeron must mean complete isolation of the individual within the masses.

To a certain extent Birnstrudl is mirrored in the play by Wondrak. Like his human counterpart this "armer Teufel" (III, 145) serves a difficult master, Maskeron. Despite being immortal ${ }^{119}$, Wondrak has little to be happy about.

119 Indeed much of the humour in the play comes from the incongruity of Wondrak's ever so 
A burdensome family (III, 136, 149) necessitates his supplementing his income from Belial by performing at a circus and swallowing flies and mice (III, 126, 136, 149) and he suffers under the annoyance of being constantly addressed incorrectly as "Inspektor".

He well understands the method of ensnaring Pomfrit: "Verlockung, Verführung, Versprechung - aber noch keine Erfüllung" (III, 148), since he is a victim of the same tactics employed by Maskeron; in this case, the promise of a pay increase and advancement (III, 150) provides him with all the incentive he needs to pursue the aims of Belial. Nevertheless, like Birnstrudl, he has difficulty understanding Pomfrit's behaviour. That anyone might choose voluntarily to suffer leaves him dumbfounded (III, 150), and he is completely taken aback by the interference of Estrella and Thomas in his well-laid plans (III, 172-175).

Despite this, he remains confident that in the end Pomfrit will choose Belial. He reveals this, and rather too much else including his scorn for Pomfrit's intellectual Zeitleiden, to his would-be victim after overindulging:

Du wirst keine Geschichten machen, vestehst! - Du wählst uns und basta, was folgt, steht auf einem andern Blatt, bild dir nicht ein, daß du "Nein" schreien wirst, du g'scherter Intellektueller mit deinem WeltschmerzSchmäh, merk dir's, die schönste Frau der Welt ist dein, daß ich nicht lach, so ein Schlampen. $\mathrm{Pa} ß$ auf, was du in der Früh zu hören kriegst, die Sprach, dagegen red ich wie im Burgtheater ${ }^{120}$, wennst drin bist, bist drin - verstehst! - Laß alle Hoffnung fahren, speziell auf deine zwei Freunderln, Estrella, Frater Thomas, die werden von uns kuriert, dementsprechend - verstehst?

(III, 192)

Despite this slip-up, his confidence seems to be born out by their last meeting when he triumphantly insists on the contract Pomfrit has signed, unmoved by the tears and pleas for mercy: "Am Anfang lacht der Narr, der in der Hölle weint!" (III, 196).

But the play does not reveal which way Pomfrit jumps, and this has been the subject of some speculation in the secondary literature. Of those who have offered an opinion on the likely outcome on Thursday, a majority view prevails that Pomfrit will choose to keep his soul. Ian Loram is the most circumspect in putting forward the argument, suggesting it might be justified to assume that Pomfrit will be saved, but that the sequel of 1003 suggests that Hochwälder thought otherwise. ${ }^{121}$ Both Knust and Elisabeth and Felix Auer see Pomfrit's behaviour at the end as offering hope ${ }^{122}$, while Otto Rom-

human characteristics, such as: his contemplation of taking industrial action should he fail to get promotion (III, 151); his perplexity at abstract art (III, 173); and his drunken wallowing in kitsch and sentimentality when he sings of his grandmother (III, 191-192).

${ }^{120}$ It is, of course, just such a disappointment that Gustave experiences in Der verschwundene Mond.

121 Ian C. Loram, "Fritz Hochwälder", Monatshefte, 57, 1965, 13-14. 
mel, Wilhelm Bortenschlager and August Obermayer share the belief that Maskeron's uncertainty at the end means he must ultimately lose Pomfrit. ${ }^{123}$ The strongest proponent of this viewpoint is Donald Daviau, whose first two published articles on Hochwälder could lead one to believe there is no ambiguity at the end of the play at all:

Through the concern of two altruistic individuals, both of whom still believe in love and miracles, the protagonist Pomfrit [...] is restored to an understanding of life's promise and possibilities that are always available to anyone who opens his heart to them. Through his discovery of the love and concern of his fellow man Pomfrit becomes a human being again. $\mathrm{He}$ rejects Wondrak's [...] offer for success, preferring to continue the search for human happiness even with the suffering that human existence involves. He still does not believe in God, but would like to believe and hopes that he will find the way to do so ${ }^{124}$.

Of those arguing the opposite, James Schmitt is the most adamant, seeing Pomfrit as too weak to be able to resist succumbing to Belial, if not on Thursday, then at some time in the future ${ }^{125}$.

But perhaps such speculation, natural enough in the search for a moral from a morality play, diverts attention from the real message of the drama. The ending is deliberately ambiguous, for if Pomfrit is a modern Jedermann and. the play represents the dilemma Hochwälder sees facing modern humanity, then the outcome must be anything but certain. As modern technology and society develop at a break-neck speed, offering ever new comforts and devices to make life easier, yet providing more and more barriers to contact between people, the danger of individuality and personal responsibility being lost becomes greater and greater. The danger, as Hochwälder presents it, is that in a hedonistic pursuit of pleasure for pleasure's sake we may lose our identity and that which makes us human. The choice is ours, the outcome, like the ending of Donnerstag, uncertain. The ramifications of choosing pleasure without pain, of life without a conscience at all, are explored in 1003.

122 Knust, 334; Elisabeth and Felix L Auer, "Translators' Preface" to "Thursday. A Modern Mystery Play by Fritz Hochwälder", 1967, Hochwälder NachlaB, Wiener Stadt- und Landesbibliothek, Wien, 5.

Otto Rommel, "Fritz Hochwälder. Donnerstag. Ein modernes Mysterium", undated, Hochwälder Nachlaß, Wiener Stadt- und Landesbibliothek, Wien, 8; Bortenschlager, Der Dramatiker Fritz Hochwälder, 133; August Obermayer, "Hochwälders Donnerstag oder Was ein Roman aus dem Jahre 1933 und ein Theaterstïck aus dem Jahre 1959 außer dem Titel gemeinsam haben", Tausend Jahre Österreich im Spiegel seiner Literatur, ed. August Obermayer (Dunedin, New Zealand, University of Otago, German Department, 1997), 159-160.

124

Daviau, "Fritz Hochwälder", 255. While talking of the play ending in ambiguity in his earlier article, a similar line is still adopted: Daviau, "Fritz Hochwälder's Range of Theme and Form", 39. However, he is more circumspect in his most recent contribution, referring to a "gedämpften Optimismus", Daviau, "Der Konflikt [...]", 918.

Schmitt, "The Theme of Responsibility [...]", 101; cf. Harper, 48. 
Indeed, choice remains a vital consideration in each of the dramas discussed in this chapter, for while the dictates of self-interest may seem overwhelming an alternative is always present, if not always heeded. Characters reject the social values of the wider community and choose not to follow the crowd. If Augustin, in his rejection of the selfishness of those around him, can offer little in the way of a positive alternative, Marie and Genz want to improve the world. Likewise, Esther and Mordechai, Schimke, Elisabeth and Louis all turn their back on the greed and callousness of those around them, and insist on acting ethically. Justice can occasionally still be seen to be done, if only through happy chance, as in Die Herberge and Esther. Individuals can also learn the error of their ways and come to understand that the pursuit of wealth and success may not be what it promises to be, as do Lutmer and Gustave, if sometimes this knowledge comes too late. Even when the outcome is tragic, alternatives are still presented: despite its destruction the Jesuit state stands as an indictment of the brutal outside world, and the tragedy the parents bring on themselves in "Trommler" results from them knowingly doing wrong.

As the latter play shows, the inner moral voice, must be heard and acted upon. Yet often it is not merely enough not to commit evil, it is also necessary to confront it, and the burden of this responsibility rather than selfishness proves to be reason enough in several Hochwälder plays for characters to ignore the dictates of conscience. 